NBER WORKING PAPER SERIES

\title{
WHY DO TEMPORARY HELP FIRMS PROVIDE FREE GENERAL SKILLS TRAINING?
}

\author{
David H. Autor \\ Working Paper 7637 \\ http://www.nber.org/papers/w7637 \\ NATIONAL BUREAU OF ECONOMIC RESEARCH \\ 1050 Massachusetts Avenue \\ Cambridge, MA 02138 \\ April 2000
}

The author is indebted to Daron Acemoglu, Thomas Kane, Lawrence Katz, Frank Levy, Richard Murnane and Douglas Staiger for invaluable assistance. I am grateful to the Bureau of Labor Statistics Student Volunteer Program and to Jordan Pfuntner and the staff of the Occupational Compensation Survey Program for facilitating generous access to the Temporary Help Supply survey used for the analysis. Numerous personnel at temporary help firms submitted to interviews and offered their insights. I thank the National Association of Temporary and Staffing Services (NATSS) and Bruce Steinberg in particular for facilitating access to NATSS survey microdata and guiding me to other information sources throughout the industry. The views expressed herein are those of the author and do not necessarily reflect the position of the National Bureau of Economic Research.

(C) 2000 by David H. Autor. All rights reserved. Short sections of text, not to exceed two paragraphs, may be quoted without explicit permission provided that full credit, including $(\mathcal{C}$ notice, is given to the source. 
Why Do Temporary Help Firms Provide Free

General Skills Training?

David H. Autor

NBER Working Paper No. 7637

April 2000

JEL No. D82, J31

\begin{abstract}
$\underline{\text { ABSTRACT }}$
Nominally free, unrestricted training in portable computer skills is offered by the majority of U.S. temporary help supply (THS) establishments, a practice that is inconsistent with the competitive model of training. This paper asks why temporary help firms provide free general skills training. The answer proposed is that in addition to skills formation, training plays an informational role at THS firms by eliciting private information about worker ability. The model is built on the premise that training is more productive and therefore valuable to high ability workers. Firms offer a package of training and initially lower wages that induces self-selection. Workers of high perceived ability choose training in anticipation of a steeper wage profile while low ability workers are deterred by limited expected gains. Firms profit from their sunk training investment via their short-run informational advantage about ability and thereby limited monopsony power. Market competition among THS firms reduces employer rents, yielding higher wages and more training. Detailed tests of the model using representative establishment data on wages and training find strong support. The analysis demonstrates that beyond providing spot market labor, THS firms gather and sell information about worker quality to clients. The rapid growth of THS as a labor market information broker implies that the demand for worker screening is rising.
\end{abstract}

David H. Autor

Department of Economics

MIT

50 Memorial Drive, E52-380B

Cambridge, MA 02142-1347

and NBER

dautor@mit.edu 


\section{Introduction}

Open the help wanted pages of a local newspaper and you are likely to find prominent advertisements from temporary help supply (THS) firms offering free skills training in subjects such as word processing, data entry, and in some cases computer programming. Manpower, Inc., the nation's largest THS employer, estimates that it trains more than 100,000 temporaries per year in the use of office automation software. The Bureau of Labor Statistics’s (BLS) 1994 Occupational Compensation Survey (OCS) of Temporary Help Supply Services found that 89 percent of temporary workers are employed by establishments that provide some form of nominally free skills training. While not all workers train, a 1994 survey by the National Association of Temporary and Staffing Services (NATSS) found that almost one quarter of current THS workers had received skills training while temporaries (Steinberg, 1994). Training stints are normally brief but not uniformly so. Close to half of those trained received 11 plus hours of training, and a third received more than 20 hours. As Krueger (1993) reported and recent BLS analysis confirms (U.S. Department of Labor, 1996), training is almost universally given "up-front” with no explicit charge and no contractual requirement of past or continued employment.

While skills training expenditures by THS establishment are modest - estimated at 4 percent of the wages paid to trainees in 1995 and 9 percent in 1997 - the puzzle they present to the competitive model of training merits investigation for two major reasons. ${ }^{2}$ First, while Becker's (1964) Human Capital model predicts that firms will never bear the up-front cost of general skills training due to the threat of poaching or hold-up, recent theoretical work challenges this notion. Models by Acemoglu and Pischke (1998 and 1999), Chang and Wang (1996), and Katz and Ziderman (1990) demonstrate that if employers hold private information about worker ability, they will fund general skills training up-front and capture the

\footnotetext{
${ }^{1}$ Krueger's (1993) survey found that only 4 percent of THS establishments charge workers explicitly for training. The BLS Occupational Compensation Survey did not attempt to capture employee-paid training.

${ }^{2}$ Industry estimates place the average cost per trainee at \$118 in 1995 and \$150 in 1997 (NATSS, 1996b; NATSS, 1998). The 59 percent estimate of training costs relative to trainees' wage-bill is based on the following rough calculation: industry expenditures on specific skills training equaled 1.0 percent of the wage-bill in 1995 and 1.9 percent in 1997 (NATSS, 1998); and a recent survey by Autor, Levy, and Murnane (1999) estimates that 18 percent of temporary help workers receive specific skills training and a 1994 survey by the industry placed this figure at 24 percent. Assuming (of necessity) that wages and assignment lengths for trainees and non-trainees are similar, training costs roughly equal $4-9$ percent of the wage-bill of trainees. To the degree that trainees work longer stints or are in higher wage occupations, this figure would be accordingly lower. Industry
} 
returns ex post. Consistent with this hypothesis, several studies find that workers who receive general training from their employers do not appear to pay the costs through lower training wages as the Becker model predicts (cf., Bishop, 1996; Baron, Berger, and Black, 1997) [ $_{\text {Yet }}$ this evidence is far from definitive because most employer-sponsored training consists of both general and specific components. Furthermore, unobserved worker ability is likely to bias these studies against finding that trainees earn less than their marginal product during training.

By contrast, the skills training given by temporary help employers (primarily end user computer skills) is necessarily general. Moreover, the direct costs of this training which include computer equipment, instructional materials, and training staff, are borne by THS employers. Importantly, training is not restricted to workers who have already taken paid assignments. Close to half (44 percent) of all skills training is given "up front" to allow workers to qualify for their first assignments. ${ }^{1}$ Because of these institutional arrangements, the THS sector provides a unique setting for exploring whether and why firms pay for general skills training. The analysis below indicates that acquiring private information - in particular, screening worker ability - is a primary motivation.

Second and equally importantly, understanding the informational role played by employer-paid skills training at THS firms suggests a resolution to a puzzle raised recently by many analysts of the U.S. labor market (Katz and Krueger, 1999; Segal and Sullivan, 1997a; U.S. Department of Labor, 1995 and 1999): what function do THS firms serve in the labor market and why are they growing so rapidly, accounting for 10 percent of net job creation between 1990 and 2000? ${ }^{5}$ The answer proposed here is that in addition to providing labor services, THS firms gather and sell information about worker quality to the market $-\mathrm{a}$ role in which skills training figures prominently. Understood in this light, the escalating use of THS in the U.S. labor market appears something more than an outgrowth of employers' desire for flexibility. Rather,

training expense data estimates include costs of trainers, externally contracted training and certification, computer hardware and software, and rent and utilities on space used for training.

${ }^{3}$ In a similar vein, Loewenstein and Spletzer (1998) show that training in off-site vocational courses, which typically provide general skills training, increases wages with the current employer much less than wages with future employers.

${ }^{4}$ Autor, Levy and Murnane (1999), Table 5. 
the emergence of THS as a labor market information brokers suggests that employer demand for worker screening has increased dramatically.

To explore these ideas, the paper presents a simple information-based model of skills training as an ability screen and performs detailed tests using an unusual data source: a restricted access BLS industry survey of wages and training in the THS industry encompassing an estimated 19 percent of all THS establishments and 36 percent of all THS workers as of 1994. The model is premised on the view that training is more productive - and hence valuable - to high ability workers, where ability is defined as an individual's facility and motivation at learning job skills. Workers are assumed to have imperfect prior knowledge of their ability while employers cannot initially perceive ability but observe it through training. Because of the learning advantage possessed by high ability workers, firms are able to offer a package of training and initially lower wages that induces self-selection. Workers of high perceived ability choose firms offering training in expectation of wage gains in permanent employment while low ability workers are deterred by lower wages and limited expected gains. Firms profit from their training investment ex post via their short-run informational advantage about ability and thereby limited monopsony power.

The model further explores how firms may adjust wages and training to accommodate competitive pressure as proxied by a 'markup' parameter. Counter to the standard framework, the model indicates that THS firms will choose to provide more training to attract skilled workers as competitive conditions tighten. The intuition for this result is that due to their limited monopsony power, firms maximize profits by providing socially sub-optimal training - equating marginal firm benefits with costs while ignoring gains accruing to workers. When heightened market competition requires firms to raise wages, they therefore find it optimal to provide additional efficient training that increases both wages and output.

\footnotetext{
${ }^{5}$ Abraham and Taylor (1996), Autor (2000), Castro (1993), Golden and Appelbaum (1992), Houseman (1997), Mangum, Mayall and Nelson (1985), Polivka (1996), and Segal and Sullivan (1997a) offer a variety of perspectives on the recent growth of THS employment.

${ }^{6}$ One likely cause is the growth of unjust dismissal doctrine which has raised employer risks in terminating workers (Autor, 2000; Dertouzos and Karoly, 1992; Dertouzas et al., 1988; Krueger, 1991; Miles, forthcoming). Another is recent changes in the
} 
Since trainees earn less on average than non-trainees, competition squeezes employer rents, narrowing the wedge between training and non-training wages.

These predictions find strong support in the data. Wages are lower at firms offering training by a modest but statistically significant magnitude; heightened market competition, as measured by a Herfindahl index, substantially increases firms' propensity to offer free training; and, although training grows with market competition, the wage gap between training and non-training firms contracts significantly. These findings support the view that training plays an informational role in the THS market and that THS firms serve this informational role in the broader labor market. More generally, the prevalence of skills training at temporary help firms suggests that private information is a viable explanation for why firms fund workers' general human capital investments.

\section{The THS industry: context, skills training, and motivations}

\section{A. Context}

After 25 years of growth exceeding 11 percent annually, employment in the THS industry accounted for 2.6 percent of U.S. daily employment in 2000, nine times its relative size in 1972. Additionally, given turnover rates exceeding 350 percent (NATSS 1996a), the industry's point in time employment is likely to substantially understate the number of workers who have contact with it annually. ${ }_{\text {While }}$ the sources of the industry's rapid growth are a subject of controversy, recent surveys of employers' use of flexible work practices identify two sources of demand. First, employers most frequently use THS workers to fill short-term positions where the cost of searching for a temporary direct hire is likely to exceed the cost of hiring through a THS agency. Second, firms often use THS arrangements to screen candidates for permanent positions, a pattern especially prevalent among employers increasing their use of THS workers (Ballantine and Ferguson, 1999; Houseman, 1997; Staffing Industry Review, 1998).

Why workers choose THS employment is uncontroversial. Current Population Survey (CPS) and

organization of production that have increased the returns to selectivity in hiring (Acemoglu, 1999; Ballantine and Ferguson, 1999; Levy and Murnane, 1996).

${ }^{7}$ Houseman (1997) estimates that there are 7 to 8 times as many THS positions created annually as exist at a point in time. Using unemployment insurance data from the state of Washington, Segal and Sullivan (1997b) find that 5.0 percent of all Washington state workers were employed through THS firms at some point during 1993 and 1994. 
industry data demonstrate that the large majority - about two thirds - of workers choose THS as a means to find permanent work and/or to supplement income during job search, while the remaining third prefer to stay in THS (Cohany, 1996 and 1998; Steinberg, 1994 and 1998). Because workers primarily work only briefly in THS due to a lack of preferred alternatives, it is reasonable to think of the industry as facing quasi-fixed short run labor supply. In the model below, I assume that workers supply labor inelastically to the THS sector for a short period and then transition to permanent employment.

\section{B. Skills training: Methods and policies}

Job skills required by THS firms (primarily typing and clerical) were essentially static and training negligible until the proliferation of workplace computing technology generated demand for new and rapidly shifting expertise that could be mastered quickly (Oberle, 1990). As is documented in Table 1, training is now a pervasive industry feature. Of 1,002 U.S. THS establishments surveyed by the Bureau of Labor Statistics (BLS) in 1994, 78 percent offered some form of skills training and 65 percent provided computer skills training. Computerized tutorials are the most common form of instruction (82 percent), while 52 percent of establishments provide workbook exercises and 45 percent provide classroom-based training. While THS firms are prone to overstate the efficacy and depth of their training, evidence of its value is found in the fact that several leading firms sell the same training software and courses to corporate customers that they provide for free to their workers.

Almost without exception, training is given prior to or between assignments. Although workers train on their own time, they attend classes and use facilities and materials provided by the THS firm free of charge. As noted above, training is not restricted to workers who have already taken paid assignments. Autor, Levy, Murnane, 1999 (ALM hereafter) report that 44 percent of all skills training is given "up front" to allow workers to qualify for their first assignments. Trainees are not contractually bound to take

\footnotetext{
${ }^{8}$ Cohany (1998) reports that 60 of THS workers choose THS because it is the only type of work they can find, because they hope it will lead to permanent employment, or because of an unspecified economic reason. According to the 1995 CPS Contingent Work Supplement, only 16 percent of temporary workers had spent more than a year in their current assignment.

${ }^{9}$ For example, Manpower, Inc. charges its clients $\$ 150$ per trainee per day to provide its SkillWare ${ }^{\mathrm{TM}}$ training on site. In 1996 and 1997, Manpower generated approximately \$5 million annually in training revenues and trained about 35,000 workers in each year (personal correspondence, Sharon Canter, Director of Strategic Communications, Manpower, Inc., 1998). Manpower also states that 88 percent of Fortune 100 companies have engaged it to provide computer skills training.
} 
or retain a job assignment afterwards, nor would such a contract be enforceable.

As documented in Table 1, firms employ several training policies: managers select trainees (44 percent), clients request and fund training (46 percent), and, most prevalently, all volunteers are trained (85 percent). Since policies are not mutually exclusive, one might assume that more restrictive policies are applied to more valuable forms of training (e.g., computer skills). Yet, among establishments that provide computer training exclusively and report only one training policy, 62 percent provide strictly voluntary training. Hence, it appears that computer (and other) training is given primarily on an 'as requested' basis.

\section{Skills training: The Human Capital model}

These facts run counter to the Human Capital model of training (Becker, 1964). In the competitive case analyzed by Becker, workers pay for general skills training by accepting a wage below their marginal product during training. The threat of poaching or hold-up ensures that workers earn their full post-training marginal product and hence up-front general skills training is not provided. By contrast, THS firms routinely give training up-front during unpaid hours and hence the opportunity for workers to defray costs through a contemporaneously lower training wage is essentially non-existent.

While several alternative explanations for these facts are conceivable within the standard framework including skill-specificity, labor market monopsony, and low rates of worker turnover - none appears relevant. On the first point, if skills provided are firm-specific and hence (by definition) have no outside market value, firms may invest in training up-front and reap returns ex post. Yet, logically, THS firms must - and do - train in skills broadly demanded by their many clients, i.e. general skills that have many buyers. Limited worker mobility after training might also make up-front training profitable, for example if THS firms effectively operated 'company towns.' Yet THS markets are generally not concentrated in a conventional sense, with most localities served by multiple firms. Finally, it is a common assumption in the literature that low employee turnover facilitates employer-sponsored general skills training since workers are unlikely to depart after training (Blinder and Krueger, 1996; OECD, 1993). If this argument is correct then THS establishments - where turnover averages several hundred percent - are an 
improbable venue for training.

\section{Skills training: Alternative motivations}

THS managers interviewed for this research primarily cited three motivations for training: worker recruiting/screening and retention, quality differentiation, and skill development. These ideas are discussed in turn. 10

Because turnover is high, recruiting at THS establishments is ongoing. Applicants to THS firms are heterogeneous, often having short work histories, limited credentials, and recent spells of unemployment (Houseman and Polivka, 1998; Segal and Sullivan, 1997a). While THS firms offer a variety of benefits to attract workers, training is distinct because it is thought to differentially attract desirable workers.

Training facilitates recruitment and assessment in three ways: pre-training exams measure the skills that workers possess; tests before and after training permit firms to gauge workers' ability to absorb new skills; and workers' motivation to take training is itself considered an emblem of skill or desirability. 1. These facts concord with numerous findings in the economics literature that suggest that training and ability are complements. For example, Acemoglu and Pischke (1998), Altonji and Spletzer (1991), and Bartel and Sicherman (1998) report that workers with higher skills as measured by standardized test scores are more likely to receive training, even conditional on education.

The view that training facilitates worker screening is also prevalent in the THS industry literature. For example, the industry trade association's guide How to Buy Temporary Help/Staffing Services offers this advice to client firms:

How are potential temporary employees screened and tested? Does the company offer any training programs? This may help you determine the "quality" of workers you receive.

A Manpower, Inc. advertisement to customers reads:

Manpower offers our employees many ongoing training opportunities - at no charge. This helps them increase their marketability and wage earning potential. Plus, it helps Manpower

\footnotetext{
${ }^{10}$ Interviews were conducted with approximately two dozen THS executives. Additional fieldwork included performing site visits to THS firms, undergoing skills training and testing with software and materials provided by various firms, registering as a THS worker, and conducting a national survey of THS establishments (analyzed in Autor, Levy, and Murnane, 1999).

${ }^{11}$ In all cases the author observed, training began and ended with assessment. Firms can of course test without training and some do. This is unlikely to be as informative about ability, however, because testing will not normally gauge either motivation or facility at learning.
} 
and Manpower Technical continue to attract and retain the best workers.

In addition to worker screening, these quotations suggest a related motivation for training: retaining high quality workers. This view is consistent with the formal notion that private information developed during training binds workers to firms, making turnover unattractive. While, perhaps unsurprisingly, THS managers do not name asymmetric information as central to worker retention, they describe personnel policies consistent with it. Workers are normally first placed at lower wage, lower skill assignments and given better placements as they demonstrate success. Workers who test and train successfully and perform well at assignments advance more rapidly while workers who perform poorly are rarely offered additional placements. Consequently, poor workers disproportionately turn over while good workers frequently remain. At a point in time, the incumbent employer knows more about worker quality than its competitors, potentially giving rise to limited monopsony power.

It is important to observe that the THS market is characterized by vertical (quality) differentiation, with competing firms offering differing packages of cost and service. In a differentiated market, firms occupying the 'high end' niche may need to carefully screen workers to meet customer expectations while 'low end' firms may find it equally profitable to hire all comers and charge clients a lower fee accordingly. As a rule, providing testing and training helps THS firms to develop a reputation for quality. ${ }^{12}$ For example, an article in Purchasing states (Evans-Correia, 1991):

Most buyers agree that testing and training do make a more reliable worker... Businesses will have to pay a premium for temporaries with extensive testing and training. But... 'it's worth it.'

A final motivation for training is of course skill development. While in theory training could serve only a signaling role as in Spence (1973), the evidence cited above suggests that workers do gain marketable skills from the training experience.

Results from ALM's survey of THS establishments support these qualitative observations. Managers of THS establishments rated the following as important motivations for offering free skills training: 
demonstrating a commitment to quality to customers (81 percent); improving workers' performance at assignments (79 percent); and recruiting or retaining workers (75 percent). Asked about the role that skills training plays in recruiting, a substantial majority reported that "offering training particularly attracts applicants with strong motivation" (91 percent) and "good skills" (77 percent). 13

\section{Model}

\section{A. Context}

This section formalizes the ideas above - self-selection, private information, and skill development into an illustrative model of training in the presence of private information and derives testable implications. The model is related to work by Spence (1973), Salop and Salop (1976), and Acemoglu and Pischke (1998 and 1999). Salop and Salop advanced the hypothesis that personnel policies may induce self-selection among workers possessing private information about their characteristics, a hypothesis tested in the context of employee pensions by Ipollito (1997). 14 The model parallels Spence in that workers signal private knowledge about ability by their willingness to engage in a costly activity (i.e., taking lower wages). ${ }^{15}$ However, unlike both Spence and Salop and Salop, the present model leverages the notion that once incumbent employers have privately observed worker ability, they hold limited monopsony power. The model's monopsony component is related to Acemoglu and Pischke (1999: AP hereafter) and for the reader's convenience, I use their notation where possible. ${ }^{6}$

The model differs from AP and other previous work in important respects. First, whereas AP view training's role as strictly one of increasing output, the current model offers a theory of training as a screening device used by employers to induce self-selection among workers of different unobserved ability. Second, while AP examine only the case where monopsony profits are restricted to zero, the

\footnotetext{
12 Since customers rarely see the same THS worker twice, the expectation of quality is critical. For example, Mitchell Fromstein, former CEO of Manpower Inc., is paraphrased in Oberle (1990) as saying, “... the training, even if it's bestowed on an employee only for a short period, helps build good client relationships and the organization collects on the good will over time."

${ }^{13}$ Results are from a sample of 603 establishments with a response rate of 73 percent (438 interviews). Fifty-seven percent of participants provide free skills training. For responses tabulated above, the category 'agree' combines 'agree' and 'strongly agree', and conversely for disagreement. See Autor, Levy and Murnane (1999) for details.

${ }^{14}$ See Heckman and Sedlacek (1985 and 1990) for a richer treatment of self-selection equilibria in labor markets.

${ }^{15}$ Hence, the model posits an implicit market for training as in Rosen (1974).

${ }^{16}$ Gibbons and Katz (1991) also explore the role of private information in labor markets although outside the training context.
} 
current model explores how monopsonistic firms may optimally adjust training to accommodate varying competitive conditions. Each of the three empirical implications derived and tested below is unique to the current model.

\section{B. Environment}

The model is a repeated three period game. ${ }^{7}$ In the first period, THS firms hire workers and provide general skills training. Period 1 employment and training are publicly observed. Consistent with the upfront policies at THS firms, no production occurs during the training period and no contracts are signed for post-training employment. At the end of the first period, competing THS firms may make wage offers to attract trained or untrained THS workers. Workers who receive a superior wage offer accept it.

Additionally, for exogenous reasons, workers separate from their first period firm with probability $\lambda$. In the second period, workers are assigned by their THS firms to client sites where they produce output. Clients pay the THS firm an hourly 'bill rate' equal to the expected productivity of workers assigned to them. Workers receive an hourly wage from the THS firm that may differ from the bill rate. In the third period, workers are hired into the permanent sector.

Workers may be of either two abilities, $\eta \in\{H, L\}$, where without loss of generality, I normalize $H=1$ and $L=0$. The distribution of worker ability is given by the parameter $\rho$ which is the fraction of type $L$ workers in the population, known to firms, workers and clients. A worker's output at the client site is given by $f(\eta, \tau)=\eta(1+\tau)$ where $\tau$ is the amount of general skills training provided by the THS firm. This multiplicative specification embodies the observation that workers of high ability benefit more from training. 18 The training cost function $c(\tau)$ is assumed everywhere strictly increasing, convex and differentiable with $c(0)=c^{\prime}(0)=0, c^{\prime}(\cdot)>0, c^{\prime \prime}(\cdot)>0$ and $\lim _{\tau \rightarrow \infty} c^{\prime}(\tau)=\infty$. These assumptions ensure that some training is socially optimal. ${ }^{19}$ Firms, clients and workers are risk neutral.

\footnotetext{
${ }^{17}$ The repeated game structure assures that firms adhere to their advertised policies. I assume that deviating firms are punished in perpetuity by workers who follow a trigger strategy. Successive generations of the game overlap since a new pool of workers enters in each period.

${ }^{18}$ Any concave function with positive cross-partial derivatives between training and ability would work equally well.

${ }^{19}$ The normalization $\mathrm{L}=0$ means that low ability workers should not receive any training. More generally, the model indicates that high ability workers should receive more training than low ability workers.
} 
There is no discounting and workers maximize income over the three periods. Worker utility is therefore $U_{i}\left(w_{1}, w_{2}, w_{3}\right)=w_{1}+w_{2}+w_{3}$ where $w_{t}$ (assumed non-negative) is a worker's wage in period $(\mathrm{t})$.

The flow of asymmetric information about ability drives the model. To capture the idea that workers hold initially superior information, I assume that workers are ex ante indistinguishable to firms but that each worker receives at the outset an imperfectly informative signal $\beta$ about his or her own ability where $\beta \in\{h, l\}$. High ability workers are more likely to receive a type high signal than are low ability workers but no worker learns his type with certainty and, of course, workers understand that the signals are probabilistic. I refer to $\beta$ as the worker's beliefs. The probability that a worker is of a given ability type (high or low) conditional on his beliefs is $P(\eta=H \mid \beta=h)=\delta_{h}>(1-\rho)$ and $P(\eta=H \mid \beta=l)=\delta_{l}<(1-\rho)$ where $1>\delta_{h}>\delta_{l}>0$. This strict inequality indicates that workers' beliefs are informative but not infallible.

While firms cannot initially distinguish worker ability, a central observation above is that firms learn about ability via training. In the model, THS firms performing training will observe worker ability fully in period 1 (prior to placement) whereas non-training firms will not. Consistent with the survey evidence indicating that clients use THS arrangements to screen for permanent positions, I lastly assume that ability becomes public knowledge during the second period while workers are at client sites. 21

Based on this structure, I first analyze the partial equilibrium case in which there are two firms - a training and non-training firm - earning unequal profits, and then generalize the model to explore how free entry (and, hence, equalized profits) impact training provision. 2

\subsection{Partial equilibrium: the restricted entry case}

Depending on parameter values, the model can produce several equilibria: a pooling equilibrium in

\footnotetext{
${ }^{20}$ The non-negativity assumption is reasonable in light of the fact that a majority of THS workers are likely to be capital constrained (cf., Cohany, 1996 and 1998).

${ }^{21}$ These assumptions are stated in their strongest form. All that is required is that workers have superior initial information about their ability and that, after hire, incumbent THS employers improve their informational position via training relative to outside THS employers. Whether workers also update their beliefs is not consequential to the results.

${ }^{22}$ While I do not explicitly model here why permanent sector firms use THS workers, the extension is immediate. If permanent sector firms cannot costlessly terminate workers (or renegotiate wages) after observing ability, they will prefer to use THS
} 
which all workers prefer not to train and hence none is offered; a pooling equilibrium in which all workers prefer training and receive it; and a separating equilibrium in which workers with high ability beliefs prefer training while those with low beliefs do not. This third case gives rise to a heterogeneous training environment in which a subset of firms provide training. This is the equilibrium of empirical relevance and it is analyzed below. Alternative equilibria are discussed in section A of the Appendix.

\section{A. Wages at the separating equilibrium}

Working backwards from the separating equilibrium, I assume initially that there are two THS firms, one offering training and the other not. Label these Firms 1 and 0 respectively ( $F \in\{1,0\}$ ). Subsequently, I derive the conditions that support worker separation by ability. Starting with the final (third) period, it is immediate that workers' permanent sector wages are set according to individual ability (publicly observed in period 2) and training received (publicly observed during period 1).

$$
w_{i, 3}\left(\eta_{i}, \tau_{i}\right)=\eta_{i}\left(1+\tau_{i}\right)
$$

Wages in period 2 will be set by competition among THS firms for labor. A firm that wishes to retain a given worker in the second period must pay at least her opportunity wage. This opportunity wage is determined by the expected productivity of workers that separate from their period 1 firm for a given wage offer. The expected productivity of separators, denoted by $v(\tau)$, is given by their expected ability and training received:

$$
v(\tau)=E\left(\eta_{\lambda}\right) \cdot(1+\tau)
$$

At the separating equilibrium, Firm 0's applicant pool is composed exclusively of low ability belief workers. Because it does not observe actual worker ability during period 1, Firm 0 deploys all applicants to client sites in period 2 except for the fraction $\lambda$ that turns over exogenously. Since Firm 0's separators are a representative subset of applicants and have not received any skills training, it follows that $w_{2}(0)=v(0)=\delta_{l}$

At the training firm, the applicant pool contains only high ability belief workers. Given that beliefs are

arrangements to perform prior screening and to fill short duration positions where the expected labor plus termination costs 
not fully informative, a fraction of these $\left(1-\delta_{h}\right)$ are of low ability. ${ }^{2 .}$ Observe that because applicants are ex ante indistinguishable, Firm 1 will provide the same training to each. After training, the firm loses $\lambda$ of its period 1 recruits to exogenous turnover. In addition, it will use its private information about ability acquired during training to remove unproductive workers. Workers of low ability are offered a wage of zero, their revealed productivity. Since some high ability workers have turned exogenously, all low ability workers also separate to pool with the exogenous departures. Consequently, Firm 1 separators are a mixture of exogenous departures of expected ability $\delta_{h}$ and endogenous departures, all of low ability $(\eta=0)$. Substituting into (2) outside firms will assess the expected productivity of Firm 1 separators as:

$$
\nu(\tau)=\frac{\lambda \delta_{h}(1+\tau)}{\lambda \delta_{h}+\left(1-\delta_{h}\right)} .
$$

This equation has three implications. First, because outside THS firms cannot distinguish exogenous from endogenous Firm 1 separators, all Firm 1 separators workers command a wage of only $v(\tau)$. Second, because training only benefits high ability workers, wages in the outside market for Firm 1 separators rise less than one-for-one with training (observe that $v^{\prime}(\tau)<1$ ). Third, because Firm 1 privately observes each worker's ability during training, it will counter any wage offered to its workers except a wage that exceeds their productivity. Poaching is therefore unattractive. Accordingly, Firm 1 need only pay second period wages of $w_{2}(\tau)=v(\tau)$, although all retained workers are of high ability. 24

A key result of this information structure, visible from (3)] is that high ability trainees receive less than their marginal product during period 2. How much less? A comparison of $v(\tau)$ and $v(0)$ reveals that wages at Firm 1 may well be lower than at Firm 0, even though ability and training are both higher. This result follows from the fact that it is not productivity that sets wages at Firm 1 but rather the degree of adverse selection in the outside market. I return to this result below.

\footnotetext{
exceed the cost of a THS arrangement (including the markup as below).

${ }^{23}$ Hence at a separating equilibrium, workers and firms are equally informed of each workers' ability belief since only high belief workers apply to training firms and only low belief workers apply to non-training firms. Actual ability, however, is observed only by the training firm in the subsequent period.

${ }^{24}$ See section B of the Appendix for a more detailed proof.
} 


\section{B. Client revenue and profit maximization}

Since training is publicly observable and population parameters are commonly known, a client's willingness to pay for THS workers from a given firm is simply the expected productivity of workers retained into the second period. The firm's bill rate, $R(\tau)$, will equal this expectation in equilibrium:

$$
R(\tau)=E(\eta) \cdot(1+\tau)
$$

It is immediate that $R(0)=w(0)=\delta_{l}$ and $R(\tau)=(1+\tau)$.

Substituting Firm 1's bill rate into its objective function and using $v(\tau)$ for $w_{2}(\tau)$ yields:

$$
\max _{w_{1}, \tau} \pi=(1-\lambda) \delta_{h}[R(\tau)-v(\tau)]-c(\tau)-w_{1} \quad \text { s.t. } w_{1} \geq 0
$$

Firm 1 chooses wages and training $\tau^{*}$ to maximize profits and the first order condition for training is:

$$
c^{\prime}\left(\tau^{*}\right)=(1-\lambda) \delta_{h}\left[1-v^{\prime}(\tau)\right], w_{1}=0
$$

This condition will be satisfied at $\tau^{*}>0$ (and therefore $\pi^{*}>0$ ) since $R^{\prime}(\tau)=1, v^{\prime}(t)<1$ and $c^{\prime}(0)=0$. Hence, although training is provided 'up-front,' Firm 1 is able to recoup its investment ex post by capitalizing on its informational advantage developed during training. 25

\section{Conditions for worker separation}

For workers to separate by ex ante ability beliefs, wages and training must satisfy the participation and separating constraints - the conditions under which high type workers are recruited to firm 1 while low type workers decline to apply there. Workers will apply to the firm where expected utility, the sum of periods 1, 2 and 3 wages, is highest conditional on prior beliefs.

For high ability belief workers, this implies a participation constraint of $\delta_{h} \tau^{*}>v(0)-v\left(\tau^{*}\right)$. High type workers apply to Firm 1 even if wages are as much as $\delta_{h} \tau^{*}$ lower there because training yields an expected wage gain of $\delta_{h} \tau^{*}$ in period 3. For low ability belief workers, the separating constraint is analogous but the inequality is reversed and $\delta_{l}$ replaces $\delta_{h}: \delta_{l} \tau^{*}<v(0)-v\left(\tau^{*}\right)$. Low belief workers will

\footnotetext{
${ }^{25}$ Note that in this two firm case, first period (training) wages are zero although they may be positive in the free entry case explored below.
} 
also accept a lower wage at the training than non-training firm. Critically, since high belief workers gain more in expectation from training, they will accept a larger period 2 wage deficit at the training firm.

Combining these inequalities gives the necessary and sufficient condition for worker separation:

$$
\delta_{h} \tau^{*}>v(0)-v\left(\tau^{*}\right)>\delta_{l} \tau^{*}
$$

In words, at a separating equilibrium, the expected period 3 wage gain for high belief workers offsets (at a minimum) their training wage penalty in period 2, while the opposite is true for low ability belief workers. Notice that a necessary implication of $(7)$ is that $v(0)-v\left(\tau^{*}\right)>0$. Wages at the training firm are lower than at the non-training firm, an implication tested empirically below.

We can characterize wages and self-selection in the labor market when (7) is satisfied. All high ability belief workers are recruited to Firm 1 where they receive up-front training $\tau^{*}$ in period 1 , wage $v\left(\tau^{*}\right)$ in period 2, and wage $\eta_{i}\left(1+\tau^{*}\right)$ in period 3 , where $\eta_{i}=1$ with probability $\delta_{h}$ and 0 otherwise. All low ability belief workers are recruited to Firm 0 where they receive no training in period 1, a wage of $v(0)$ in period 2, and a wage of $\eta_{i}$ in period 3 where $\eta_{i}=1$ with probability $\delta_{l}$ and 0 otherwise. ${ }^{66}$ Note that these results are only a partial equilibrium, however, inasmuch as entry is restricted to two firms and profits are not equalized between them. 27 These strictures are inessential and I relax them in the next section.

Returning momentarily to the institutional details of THS employment, these private information based results appear reasonable in a labor market with a relative abundance of new entrants, recent job losers, and individuals with extended time out of the labor force and/or limited labor force attachment. THS managers interviewed for this research were skeptical of workers' resumes and relied on assessment and demonstrated performance via job training and job placements to draw judgments. There is little question that incumbent THS employers develop a better informational position regarding worker ability than do outside buyers.

\footnotetext{
${ }^{26}$ It bears emphasis that for the separating equilibrium to occur, workers' prior ability beliefs must not be fully informative. If workers knew their ability with certainty, no low ability workers would apply to Firm 1 implying no informational monopsony would be present in period 2 and hence no up-front training would be given in period 1. Up-front training must therefore generate private information for firms to find it profitable.

${ }^{27}$ Specifically, Firm 1 earns positive profits while Firm 0 does not.
} 


\subsection{Equilibrium: The impact of competition on training and wages}

In this section, I relax the maintained restrictions on entry and profitability to explore the comparative statics of training and wages under a range of market conditions proxied here by a profit parameter. This parameter, $\pi \geq 0$, will equal the minimum per-worker profit or 'markup' demanded by each incumbent or entrant THS firm including any firm engaged in poaching. ${ }^{2.8}$ This reservation profit parameter may arise in several contexts, for example from a fixed cost of market entry that serves as a profit floor as in Salop (1979) or from Cournot competition among market incumbents (cf. Tirole, 1988, section 5.5). In the empirical work ahead, I use a Herfindahl index to proxy market conditions and hence either interpretation is natural. 29

For the remainder of the analysis, I allow an unspecified number of training and non-training firms, which I refer to as firms of Types 1 and 0 . I continue to assume that (7) is satisfied, i.e., the separating equilibrium holds. Competition and/or entry will ensure that per-worker profits are reduced to $\pi$ at each firm and further that all firms of a given type employ the same wage and training policies. Since firms compete for both workers and clients, competition could arise in the product or labor market or both. To simplify, I maintain the assumption that clients pay expected productivity and hence the locus of competition is the labor market. An important assumption is that while competition dissipates rents arising from asymmetric information, it does not dispel asymmetric information directly since firms must continue to test and train to observe ability.

\section{A. Equilibrium wages under multiple entry}

We can recalculate firms' wage policies in light of these conditions. At non-training firms, the minimum profit requirement is simply reflected in a debit to the wage of each worker:

$$
v(0, \pi)=\delta_{l}-\pi
$$

\footnotetext{
${ }^{28}$ For non-training firms, the markup is earned on workers deployed to the client site since these firms make zero gain or loss on workers that turn over in period 1. For training firms, the markup will equal the average per-worker difference between client receipts and total costs (wages plus training) for all trainees, including those lost to turnover. If, instead, the profit metric excluded separators, training firms could make net losses even while earning positive 'profits,' which would not be an equilibrium.
} 
Since Type 0 firms hire all comers and pay ex ante expected productivity, this wage policy generates profits equal to the profit floor and cannot be profitably poached. Note that if wages are specified in logarithms, $\pi$ is simply a percentage markup of the bill rate over the wage.

Outside wages for Firm 1 separators will now be determined by the expected productivity of separators minus the markup:

$$
v\left(\tau^{\pi}, \pi\right)=\frac{\lambda \delta_{h}\left(1+\tau^{\pi}\right)}{\lambda \delta_{h}+\left(1-\delta_{h}\right)}-\pi
$$

Notice that the profit parameter enters the outside wage function twice: directly because, in equilibrium, firms hiring separators must receive the reservation profit; and indirectly, because firms' training levels, $\tau^{\pi}$, must respond to changes in $\pi$. Whereas Type 1 firms previously chose training via an unconstrained profit maximization, they now choose training to maximize worker utility (i.e., the sum of workers wages over three periods) subject to the minimum profit constraint, $\pi$. Substituting (1) for period 2 wages and (9) for period 3 wages in the worker's utility function, we have the firm's maximization:

$$
\begin{aligned}
\max _{w_{1}, \tau} E\left(w_{1}+w_{2}+w_{3} \mid \beta=h, F=1\right)=w_{1}+v(\tau, \pi)+\delta_{h} \tau \\
\text { s.t. } \quad(1-\lambda) \delta_{h}[(1+\tau)-v(\tau, \pi)]-c(\tau)-w_{1} \geq \pi, \quad w_{1} \geq 0
\end{aligned}
$$

Observe that if a firm failed to maximize worker utility for a given profit level, a competitor - also making profits $\pi$ but offering a preferred combination of wages and training - would attract all high ability belief workers.

\section{B. Comparative statics}

Solving (10) for $\tau^{\pi}$, the firm's optimal training choice given $\pi$, yields the following expression for training as a function of reservation profits and worker ability:

$$
c\left(\tau^{\pi}\right)=\min \left[\left(1+\tau^{\pi}\right)(1-\lambda) \delta_{h}\left[1-\frac{\lambda \delta_{h}}{\lambda \delta_{h}+\left(1-\delta_{h}\right)}\right]-\pi\left[1-(1-\lambda) \delta_{h}\right], c\left(\tau^{* *}\right)\right]
$$

where $\tau^{* *}$ is defined as the training level that maximizes social output during the remaining two periods

\footnotetext{
${ }^{29}$ More generally, as is well known, firms facing a constant elasticity of product demand (or labor supply) will optimally set prices (wages) at a price-cost markup (markdown) inversely proportional to this elasticity. If, plausibly, added market
} 
and hence satisfies $c^{\prime}\left(\tau^{* *}\right)=2 \delta_{h}$. Totally differentiating (11) and rearranging yields:

$$
\frac{d \tau^{\pi}}{d \pi}=\left\{\begin{array}{cl}
-\frac{\left(1-(1-\lambda) \delta_{h}\right)}{c^{\prime}\left(\tau^{\pi}\right)-c^{\prime}\left(\tau^{*}\right)}<0 & \tau^{*} \leq \tau^{\pi}<\tau^{* *} \\
0 & \text { elsewhere }
\end{array}\right.
$$

where $c^{\prime}\left(\tau^{*}\right)$ is given by (6) As is shown in section $\mathrm{C}$ of the Appendix, this derivative is negative, implying that heightened competition (i.e., a fall in $\pi$ ) generates an increase in training so long as training is not already at the social optimum, $\tau^{* *}$ (an unlikely case).

The intuition for this result is visible in Figure 1 which plots the marginal cost of skills training against the marginal gain to revenue, apportioned between worker wages and firm profits according to the adverse selection condition set by (3). In the unconstrained profit maximizing case, the firm chooses training to equate marginal training cost with marginal private gain, depicted as point $\tau^{*}$ in the figure, while ignoring the wage benefits accruing to workers. Training is therefore socially suboptimal. Now consider a case where, in response to competition, the firm wishes to increase workers' earnings by the area A-B-C-D. One response is for the firm to pay A-B-C-D out of profits. Alternatively, the firm can increase training from $\tau^{*}$ to $\tau^{* *}$, thereby raising earnings equivalently but at cost A-C-D, which is strictly less than A-B-C-D. Because the firm is able to provide additional training at an expense below the combined marginal benefit to firm and worker, it necessarily chooses to provide more training when competition requires it to raise wages.

The second key comparative static result is that wages rise with competition. Wages at non-training firms rise one-for-one with competition as is seen by differentiating (8) with respect to the markup: $\partial v(0, \pi) / \partial \pi=-1$. By contrast, wages at training firms move more than one-for-one with the markup since competition induces wage changes both directly through $\pi$ and indirectly through $\tau^{\pi}$ :

competition increases this elasticity, firms will reduce their markups (markdowns) accordingly.

${ }^{30}$ By an application of the envelope theorem, it is shown in section D of the Appendix that at $\tau^{*}$, the net cost of increasing wages by a small amount through additional training is zero. 


$$
\frac{d \nu\left(\tau^{\pi}, \pi\right)}{d \pi}=\left\{\begin{array}{cl}
-1+\frac{d \tau^{\pi}}{d \pi}\left[\frac{\lambda \delta_{h}}{\lambda \delta_{h}+\left(1-\delta_{h}\right)}\right]<-1 & \tau^{*}<\tau^{\pi}<\tau^{* *} \\
-1 & \text { elsewhere }
\end{array}\right.
$$

Recall, however, that in the separating equilibrium, wages at training firms are below those of nontraining firms. Hence, a third implication is that the predicted effect of competition is to limit the rents firms extract from workers, narrowing the wedge between training and non-training wages.

To close the model, note finally that first period (training) wages at Type 1 firms can be positive under some market conditions. Specifically, solving (11) for Type 1 firms' first period wage yields:

$$
w_{1}\left(\tau^{\pi}, \pi\right)=\max \left[0, \pi\left(1-(1-\lambda) \delta_{h}\right)+c^{\prime}\left(\tau^{*}\right)\left(1+\tau^{* *}\right)-c\left(\tau^{* *}\right)\right]
$$

Although this wage is zero for most parameter values, if per-worker profits exceed $\pi$ when training is at its social optimum, Type 1 firms will disgorge excess earnings by paying positive training wages. 1.

\section{Empirical implications}

In the subsequent sections, I test the three major predictions of the model. First is the proposition from (7) that wages (for comparable jobs) pay less at training firms than non-training firms, a 'separating' condition necessary for training to yield self-selection by ability. The second prediction explored is whether in response to market competition, firms provide more free skills training. Finally, I ask whether wage gains spurred by competition are comparatively larger for workers at training than non-training firms. Each of these theoretical predictions receives empirical support. I also discuss alternative interpretations and provide supplementary evidence using survey data from ALM.

\section{Data description}

The BLS Occupational Compensation Survey of Temporary Help Supply Services (OCS hereafter) provides a unique data source for analyzing the relationships among wages, training, and competition at temporary help establishments. ${ }^{32}$ Conducted in 1994, the survey enumerates employment, wages, training offerings, and training policies at 1,033 temporary help establishments in 104 Metropolitan Statistical

\footnotetext{
${ }^{31}$ The THS establishment survey performed by Autor, Levy, and Murnane (1999) captured several examples of THS establishments paying positive wages during training, typically at the rate of \$1 per hour.
} 
Areas (MSAs), Primary Metropolitan Statistical Areas (PMSAs) or non-metropolitan counties throughout the U.S (which, for brevity, are referred to as MSAs). An establishment is defined as all outlets of a firm in an MSA and may encompass multiple offices. Thirty-eight percent of establishments belong to firms residing in multiple regions. The sample comprises an estimated 19 percent of all THS establishments employing 20 or more temporary workers in 1994 and 34 percent of all THS employment. 33

Surveyed establishments provided data for a payroll reference month on the hourly wage of assigned THS workers classified into 47 detailed technical, clerical, blue collar, and service occupations. For brevity, I refer to the first three of these groups as white collar, clerical/sales, and blue collar respectively. Service occupations (3.9 percent of the sample) were excluded from the analysis because they do not normally receive training, as were observations where occupation was unspecified, leaving 333,888 observations at 1,002 establishments. 34

In addition to wages and job titles, the primary component of the survey used below is detailed information collected on skills training subjects and policies summarized in Table 1. Respondents reported whether they offer skills training to each 'collar' in 8 subject categories: word processing, data entry, computer programming languages, workplace rules and on the job conduct, customer service skills, interview and resume development skills, communications skills, and other. I focus here on computer skills because they are well defined, hold market value, and clearly constitute general skills training.

Training policies were categorized as: all workers receive some training; workers volunteer; establishment selects workers for training; and clients request and pay for training. Multiple responses were permitted. Unlike the training subject data, these policies refer to the entire establishment rather than workers in a collar. If a firm specifies multiple training policies, it cannot normally be determined which

\footnotetext{
32 The author was permitted supervised access to this confidential BLS survey under the auspices of the BLS Student Volunteer Program.

${ }^{33}$ Franchises of a firm are counted as independent establishments. The mean number of establishments owned by multi-region firms is 7.9 with a standard deviation of 14.2. Confidentiality requirements prevent disclosure of the range of establishments owned by multi-region firms. The survey universe includes only establishments with 20 plus workers. It is likely that establishments with fewer workers provide a negligible share of THS employment.

${ }^{34}$ Inclusion of service occupations changes none of the substantive results. White collar occupations include professional specialty, technical occupations, accountants and executive, administrative, and managerial occupations. Clerical occupations include marketing, sales, and clerical and administrative support occupations. Blue collar occupations include precision
} 
policy applies to what subjects and/or worker groups. For purposes of the empirical work, I combine the 'all workers trained' category with the 'workers volunteer' category into a 'all/volunteers' category because it is apparent that many establishments that report training all workers actually train all workers who volunteer. Since the majority (62 percent) of firms that checked the 'all' category also checked the 'volunteers' category, this decision had little impact on the substantive results. Firms that did not report any training subjects (or only reported 'other') were coded as non-training firms, and firms that offered training only to a specific collar(s) were coded as non-training firms for the collar(s) that they do not train. .5 The data do not enumerate which workers receive what training or what fraction is trained. To account for the pairing of individual worker wage data with establishment level training data, I use Huber-White standard errors with a clustering correction throughout. For further discussion of the OCS survey, see U.S. Department of Labor, 1996

\section{Empirical results}

As is seen in Table 1, the vast majority - 78 percent - of temporary help establishments provide skills training to their workers. Sixty-five percent of establishments provide computer skills training while 70 percent train in the 'soft skills' listed in the previous section. While these figures are weighted by BLS national probability weights, the picture of extremely prevalent skills training at temporary help establishments is unaltered by using unweighted, area-weighted, or employment-weighted frequencies.

\subsection{Are wages lower at training establishments?}

For up-front skills training to induce self-selection by perceived ability, wages at training firms must be lower than at non-training firms. Table 2 displays summary wage data for the 333,888 worker wage observations used in the sample: 23,531 in white collar, 174,344 in clerical/sales, and 136,013 in blue

production, craft and repair, machine operators, assemblers, and inspectors, transportation and material movement occupations, and helpers, handlers, and equipment cleaners. See BLS (1996) for corresponding SIC codes and job descriptions.

${ }^{35}$ Hence, for example, if a firm had a 'client requests/pays' policy and offered exclusively word processing skills to clerical workers, it would be coded as having a 'no training' policy for white and blue collar workers.

${ }^{36}$ Two sets of BLS supplied probability sampling weights, national and area (MSA), are used for the analysis. Wage models use national weights to approximate the U.S. THS wage distribution while models of the relationship between THS market concentration and skills training or wages use area weights since the MSA is hypothesized as the relevant market. For some analyses, I also employ regional and occupational employment data from the February 1995 Current Population Survey (CPS) Contingent Worker Supplement, the CPS 1994 Outgoing Rotation Group files (ORG), and the Census 1990 IPUMS 1 percent sample (cf. Ruggles and Sobeck et al., 1997). All CPS and Census data are weighted by sampling weights. 
collar occupations. For reference, the last two columns provide wage means for THS workers from the CPS February 1995 Contingent Worker Supplement (deflated to 1994 dollars) and wage means for all hourly workers from the CPS 1994 Outgoing Rotation Groups. There is close agreement between the OCS and CPS estimates for blue collar and clerical occupations. While the match is less precise for white collar occupations, this is likely due to a small CPS wage sample for this group $(n=55)$.

\section{A. Wage differentials between training and non-training establishments}

Before turning to regression estimates, Table 3 provides a bivariate comparison of mean wages at training and non-training establishments in the 9 major occupational groups in the sample ( 3 in white collar, 2 in clerical/sales, 4 in blue collar). The comparison is striking. In 8 of 9 occupations, mean wages are lower at training establishments, with an average occupational wage difference of minus $6.4 \log$ points. Of course, these comparisons do not account for regional and occupational wage differences. To control for these factors, I estimate the following equation:

$$
W_{i j k}=\alpha+\delta T_{j}+\gamma E_{j}+O_{i}+R_{k}+\varepsilon_{i j k}
$$

where $W_{i j}$ is the natural logarithm of hourly wages of individual (i) at establishment (j) in MSA (k). $T_{j}$ is a vector of establishment training variables, $E_{j}$ is a vector of establishment characteristics, $O_{i}$ is a vector of occupation indicators, $R_{j k}$ is a vector of MSA indicators, and $\varepsilon_{i j k}$ is a random error term assumed to be composed of a person specific and establishment specific component. Given this error structure, (e1) is estimated with Huber-White standard errors that allow for clustering at establishments. The parameter of interest is $\delta$, the wage differential at training establishments. Due to the inclusion of narrow MSA and occupation indicators, $\delta$ effectively measures wage differentials among local THS establishments potentially competing for the same workers and supplying labor to the same customers.

Table 4 presents wage models for the full sample. The first column includes an indicator variable that is equal to one if the establishment provides training and 8 major occupational indicators corresponding to the occupational groups in Table 3 (a $9^{\text {th }}$ is omitted). The coefficient on the training dummy indicates that wages at training establishments are $3.4 \log$ points lower than at non-training establishments. The second 
column adds 103 MSA indicators to the model, reducing the training effect to $1.9 \log$ points. The third column replaces the major occupation indicators with 40 detailed occupation indicators, further reducing the training coefficient to $1.6 \log$ points which remains marginally significant $(\mathrm{p}=.08)$.

While these results point in the predicted direction, they mask heterogeneity among training policies. Although providing training to all workers who volunteer is the most commonplace policy (Table 1), managers and/or clients also individually select trainees at 45 percent of establishments. It is not clear that the screening model developed above should apply to these latter cases since access to training is not governed by self-selection. Hence, in columns (4) - (6) of Table 4, I estimate wage models that allow wage differentials to vary by training policy.

The disaggregated estimates found in Table 4 columns (4) - (6) indicate that the negative wage impact of employment at a training establishment is primarily accounted for by the 'all/volunteers trained' policy. The base specification in column (4) finds an estimated wage effect at 'all/volunteers' establishments of $-3.4 \log$ point. The 'firm selects' policy has an insignificant wage impact of $0.9 \log$ points, and the 'client requests/pays' policy has a marginally significant impact of $-2.7 \log$ points. After conditioning on 103 region indicators in column (5) and detailed occupational controls in column (6), the 'all/volunteers' point estimate remains highly significant at $-2.5 \log$ points. The 'client requests' and 'firm selects' policies coefficients hover near zero and are not significant. ${ }^{3}$

\section{B. Fixed effects estimates}

The wage differentials estimated above do not reflect 'training wages' in the conventional sense. Since workers take training during non-work hours, estimated differentials must reflect either pre- or posttraining wages, or a combination of the two. 8 A potential alternative reading, however, is that establishments providing 'all/volunteer' training pay lower wages not due to training but due to other

\footnotetext{
${ }^{37}$ Wage models also include controls for the log of establishment size (measured by reference month employment within-collar) and market size (measured by reference month MSA-collar THS employment), both of which are positively correlated with establishment training propensity and in the case of establishment size negatively correlated with wages.

${ }^{38}$ As noted in the data description, wage observations reported in the OCS survey are assignment wages. Since an estimated 44 percent of training is given to allow workers to qualify for their first assignment (ALM, 1999), roughly half of wage observations in the data are likely to reflect pre-training rather than post-training wages assuming that employment spells are of similar length between the two groups.
} 
amenities offered or unobserved (negative) quality differences correlated with training. One can partially explore this objection using a fixed effects strategy. As noted above, 38 percent of sampled establishments belong to multi-region firms, many of which do not offer uniform training across establishments. This within-firm variation permits inclusion of fixed effects that remove each firm's mean wage 'policy,' thereby controlling for differences in quality or amenities prevailing firm wide.

Accordingly, the fixed effects models identify average occupational pay differentials across training and non-training establishments belonging to the same firm.

To perform these estimates, I limit the sample to workers of multi-region establishments, leaving 50 firms, 395 establishments, and 201,314 worker observations. Column (1) of Table 5 presents the single training indicator specification excluding firm fixed effects and including major occupation indicators. The point estimate for the training variable is $-5.5 \log$ points. This coefficient does not prove robust to inclusion of detailed occupation controls, however. Following the previous discussion, I next disaggregate the training indicator into three policy categories. As with the pooled estimates above, it is the 'all/volunteers' policy that appears responsible for the negative training-wage relationship. Conditional on detailed controls, the all/volunteers policy remains significantly negative at $-3.7 \log$ points. Even within individual firms, only those establishments offering unrestricted skills training are found to pay lower wages than their local competitors. 10

Models were also estimated separately by collar and by major occupation ( 9 total) using both pooled and fixed effects models. Estimates of the by-collar models are found in Appendix Table A. ${ }^{1}$ These

\footnotetext{
${ }^{39}$ This strategy will clearly fail to solve the unobservables problem if there remain differences in quality or amenities that covary with training across establishments belonging to the same firm. At a minimum, however, the fixed effects estimates provide an important robustness test of the pooled estimates.

${ }^{40}$ A limitation of the estimates is that most of the standard 'observables' such as race, gender, education, and experience are absent. Despite this absence, R-squared values range from 0.50 to 0.70 for detailed models, about 40 to 50 percent higher than standard CPS cross-sectional wage regressions. One explanation for this substantial explanatory power is that the missing variables (especially education) are well proxied by occupational controls - or, that these observables' impacts on wages are largely mediated by occupation. Given the standardized occupational titles supplied by THS firms, there may be only limited additional payoff to education and experience once detailed occupation (and, implicitly, four digit industry) is controlled.

${ }^{41}$ Fixed effects estimates of policy dummies for white collar workers are difficult to interpret due to implausibly large (but in most cases statistically insignificant) coefficients. These odd results are partly explained by collinearity among policy dummies within the white collar sub-sample that makes identification of the specific policy impacts tenuous. At only 8 firms do policies vary across establishments conditional on training being provided. While further limiting the sample to these 8 firms yields somewhat more stable estimates, I conclude that the wage impacts for the white collar fixed-effects sample are not identified.
} 
disaggregated results confirm that the negative training wage relationship is pervasive among blue collar and clerical occupations, is driven by 'up-front' training policies, and is comparable in magnitude to the pooled occupation results above. White collar estimates generally find an insignificantly negative training-wage relationship.

While unobserved negative selection on ability at training establishments could give rise to similar patterns, this does not appear likely. For example, ALM report that establishments offering skills training are substantially more selective in hiring THS workers than non-training establishments. In particular, holding occupation constant, training establishments are significantly more likely than competing nontraining establishments in the same MSAs to require a high school diploma (19\%), previous experience (14\%), previous training or skills certification (25\%), and good English or verbal skills $(15 \%)$. ${ }^{4}$. As noted earlier, THS personnel interviewed for this research uniformly suggested that firms offering training attract more able and motivated workers, an idea bolstered by econometric evidence indicating that workers of greater ability - observed and unobserved - receive more training. These facts suggest that unobserved selection works against a finding of a negative training-wage relationship.

\section{Magnitudes}

While robust, it remains to ask whether the estimated wage differentials are plausible and economically significant. While these differentials are modest ( -3 to $-5 \log$ points), rough calculations suggest that they are of a reasonable magnitude. For example, data sources cited in the introduction indicate that industry expenditures on training were equal to 1.0 percent of the wage-bill in 1995 . Using the estimate from the OCS data that 73 percent of workers were employed at establishments providing training, this would imply a break-even wage differential of 1.4 percent for all skills training, a figure that should be compared to columns (1) - (3) of Tables 4 and 5.

Providing a cost estimate by policy is more difficult since industry expenditures are not tabulated in

\footnotetext{
${ }^{42}$ Wage differentials estimated by major occupation indicate that training is associated with lower wages in 6 of 9 major occupations, an effect primarily attributable to the 'all/volunteers' policy. When training subject dummies (corresponding to the 7 training areas) were included in the models, they were not as a group significant. Policy variables were robust to their inclusion.

${ }^{43}$ All estimates are significant at the 5 percent level or better. Estimates are converted from percentage points in ALM, Table 12 to percent above.
} 
this manner and policies are not mutually exclusive. On the assumption that most training costs accrue to the all/volunteers policy and further that training policies apply to equal subsets of workers at each establishment, I estimate that 52 percent of workers are impacted by voluntary training policies. ${ }^{44}$ Under this scenario, a break-even wage differential for the all/volunteers policy would be 1.9 percent, which may be compared to the estimates in columns (4) - (6) of Tables 4 and 5. Both of these estimates fall within the lower bound of the estimated wage differentials. One should bear in mind that the model does not imply training establishment wage differentials will equal training expenses. Rather, the model requires that workers are compensated for this differential by wage gains in permanent employment.

This last point underscores that an ideal data source would permit an estimate of the hypothesized wage gains that trainees receive upon entering the permanent sector. Although panel data on the wages and training of THS workers do not to the author's knowledge exist, survey data from ALM provide evidence on a closely related question: do workers at training establishments find permanent placements with greater frequency than other THS workers? Since panel data on individual earnings indicate that wages typically increase by 10 to 20 percent upon exiting the THS sector (Segal and Sullivan, 1998), a greater hiring rate out of training establishments would indicate greater expected wage gains for workers at training establishments.

THS establishments surveyed by ALM were asked the following question, "Of the workers [within the establishment's largest occupation category] who worked at an assignment last month, about what percentage were hired by a customer last month?" A regression of their responses on occupation main effects, MSA dummies, an indicator variable for whether or not the firm provides free training and an intercept yields the following estimate (standard errors are in parentheses):

\footnotetext{
${ }^{44}$ In other words, if an establishment has three training policies, I assume that each applies to one-third of workers. It is realistic to assume that the all/volunteers policy accounts for the majority of training expenses since training paid by the client is not included in industry estimates and training in which the firm selects trainees is likely to be a substantially smaller share of training. Note also that the calculation above does not imply that 52 percent of workers receive voluntary training - only that 52 percent of workers are at training establishments and covered by this policy. Since the Table 4 and 5 models estimate establishment level training differentials, the 52 percent figure is the relevant number for calculating the 'break-even' differential.
} 
(e2) $\quad$ Percent Hired $=\underset{(2.42)}{8.34}+\underset{(2.00)}{6.07 * \text { Free Training }}-0.49 *$ Clerical/Sales $-1.51 *$ White Collar

Given a base placement frequency of 10.5 percent at non-training establishments, this estimate indicates that workers at training establishments are substantially (approximately 60 percent) more likely to find a permanent placement through their THS employer in a given month. These data appear to support the model's central implication that the wage profile of workers at training firms is, on average, steeper.

\subsection{Does training increase with market competition?}

In contrast to the Becker model in which training levels are invariant to competitive conditions, the present model predicts that general skills training provision will increase with heightened market competition as firms compete to attract labor. The OCS is well suited to testing this prediction because it includes data on approximately twenty percent of the 1994 U.S. universe of THS establishments (with much greater coverage in larger MSAs). Additionally, the sampling weights implicitly provide complete information on the count and size distribution of firms not directly surveyed.

Using the weights, one may calculate a Herfindahl concentration measure for each of the three major occupations in each MSA:

$$
H_{j k}=\sum_{i=1}^{n_{k}} \omega_{i k} \cdot\left(E_{i j k} / \sum_{i=1}^{n_{k}} E_{i j k} \omega_{i k}\right)^{2}
$$

where (j) indexes occupations (white collar, clerical/sales, and blue collar), (k) indexes MSAs, (i) indexes establishments within a region, $E_{i j k}$ is establishment occupational employment, $\omega_{i k}$ is the BLS area sampling probability weight for the establishment, and $n_{k}$ is the number of establishments in the MSA. This equation is analogous to the textbook Herfindahl except that each sampled establishment's market share is deflated by the employment count at non-sampled establishments while the sum of squared market shares is inflated by the imputed shares of non-sampled establishments. ${ }^{45}$

The calculation implicitly assumes that 'collar' distributions at non-sampled establishments are comparable to those of sampled establishments and that MSAs constitute distinct THS markets. This 
latter assumption is clearly an approximation but is reasonable given that THS markets are by nature local, circumscribed by the distance THS workers are willing to commute to assignments. A complete measure of competition in the THS industry would also include factors such as the opportunity for direct hire of temporary workers by non-THS firms and the concentration of THS customers. While these measures are unfortunately not available, it is not obvious that their omission will introduce bias.

Summary characteristics of regional markets both overall and by collar are provided in Table 6 . Although THS employment is concentrated in MSAs, the point-in-time populations of THS workers are modest, averaging 1.0 percent of total employment. The mean number of THS establishments per MSA is 30.5 , although not all supply labor in each collar. ${ }^{6}$ THS market concentration in sampled MSAs is on average moderate but varies significantly. Some of the smallest non-metropolitan markets contain only a single establishment while the least concentrated MSAs have a Herfindahl of under 0.05 .

\section{A. Estimation strategy}

Using a cross-section regression to estimate the concentration-training relationship would be problematic since many local market factors may affect training such as the distribution of worker skills and preferences, demand by clients, regional price levels, etc. While one might locate proxies for some of these factors, this approach is unlikely to be convincing. An alternative strategy pursued here is to identify the concentration-training relationship using within-MSA variation in the relative concentration of white collar, clerical/sales, and blue collar occupations. Specifically, I estimate these models using the MSAcollar Herfindahl index given by (e3) while employing MSA fixed effects. These fixed effects absorb unobserved factors common to occupations in each market that affect the propensity to train while the Herfindahl coefficient is identified by intra-market variation in concentration across 'collars.'

Additionally, I control for collar main effects, within-collar occupation shares, and establishment and within-collar market size as above, all of which may be important determinants of training.

The estimating equation is: ${ }^{45}$ An establishment's area weight is the ratio of sampled to unsampled establishments in the establishment's size class in an
MSA. 


$$
T_{e j k}=\alpha+\delta H_{j k}+C_{j}+\phi S_{e j}+\zeta E_{e j}+\gamma M_{j k}+R_{k}+\varepsilon_{e j k}
$$

where (e) denotes establishments, $(\mathrm{j})$ denotes occupational collars, and (k) denotes regions. $T_{e j k}$ is an indicator variable equal to one if an establishment offers training to workers in a given collar, $H_{j k}$ is the MSA-collar Herfindahl index as in (e3). $C_{j}$ is a vector of collar main effects, $S_{e j}$ is a vector of establishment occupation share variables within collars, $E_{e j}$ is establishment-collar employment, $M_{j k}$ is MSA-collar THS employment, $R_{k}$ is a vector of MSA main effects, $\alpha$ is a common intercept, and $\varepsilon_{e j k}$ is a random error term composed of establishment, region, and occupation specific components. The parameter $\delta$ measures the degree to which if competition is relatively greater (lesser) in collar A than collar B in market 1 versus market 2, training is also relatively more (less) prevalent in collar A than B in market 1 than in market 2 .

Three computer skills training variables are used for the estimates: word processing, data entry, and computer programming languages, as well as an 'any computer skills' aggregate. Since the dependent variable is dichotomous, a non-linear model would be appropriate but is impractical due to the large number of indicator variables in the equation. Accordingly, I estimate a linear probability model with Huber-White standard errors that account for clustering within MSA-collar cells and are robust to arbitrary forms of heteroskedasticity. While the earlier results focussed on training policies and not training subjects, I focus on training subjects here for two reasons. First, the model's prediction is that firms vary their training in response to market competition while the policies that complement this training are invariant. Second and more pragmatically, the identification strategy requires an outcome variable that varies by collar, as do the training subject dummies.

The empirical strategy differs from the theory in one dimension. While the model predicts that added competition will shift the intensive margin of training, the empirical work explores its impact on the extensive margin. A practical explanation for the substitution is that the data speak only to the prevalence

\footnotetext{
${ }^{46}$ An establishment is coded as supplying labor in a collar if workers were employed in that collar during the survey reference month. It is likely that some establishments provide workers in collars not present during the survey month.
} 
of training and not its depth. More substantively, the model's prediction of movement along only one margin is an artifact of the simplifying assumption of two discrete skill groups, implying a constant 'takeup' rate. If one posits a continuous ability distribution, it is readily seen that greater depth of training implies that the participation constraint 6 is satisfied for workers lower in the distribution, leading a greater fraction to prefer training. 4

\section{B. Concentration-training estimates}

Initial estimates and specification checks using the word processing training outcome are found in Table 7. The dependent variable is equal to one if the establishment provides word processing training to a given collar. Since the Herfindahl measures increases with concentration, the predicted sign of this coefficient is negative. Column (1) estimates the bivariate training-concentration relationship and finds a significant Herfindahl coefficient of -0.25 . Column (2) adds controls for log establishment-collar and log MSA-collar employment. As would be expected, larger establishments are more likely to offer skills training. Training is also more prevalent in MSAs with greater THS employment. Conditional on these additional controls, the Herfindahl coefficient becomes insignificantly positive. The third column adds collar main effects which control for average training propensity by collar. The Herfindahl measure again changes sign, obtaining a coefficient of -0.30 , which is highly significant and remains robust to the inclusion of 102 MSA indicators in Column (4).

Subsequent columns perform two additional specification checks: removing the establishment and market size measures, and augmenting the collar main effects with 6 occupational share variables within collars. ${ }^{48}$ These substitutions have little impact on the Herfindahl coefficient or its standard error. Notably, MSA-collar THS employment is estimated to have no significant impact on training propensity in these models despite the substantial (negative) correlation between concentration and market size ( $\rho \cong-.80$ in each collar). If the Herfindahl measure merely captured differences in training propensity

\footnotetext{
${ }^{47}$ The relationship is slightly more complex than suggested since providing training to workers lower in the distribution implies a drop in average worker quality and hence an offsetting adjustment to training. If the ability distribution is well behaved (i.e., relatively smooth), however, the net effect of increased competition should be positive.
} 
prevailing in large markets, it would likely not be robust to controlling for market size. The estimates therefore show that market concentration exerts an independent effect on training. ${ }^{.9}$

The first four columns of Table 8 present the preferred (most detailed) specification above for each of three computer skills outcomes and the 'any computer training' aggregate. In each case, the concentration measure is negatively related to computer skills provision and, in 3 of 4 cases, significantly so. The most substantial relationships are found for word processing and data entry training which are also the most prevalent computer skills offerings. Paralleling the estimates in section 4.1 B, Columns (5) - (8) of Table 8 present fixed effects estimates of the training probability models. Fixed effects control for each firm's average propensity to train and hence identify the effect of concentration using within-firm, across-market variation. These models provide a check on the possibility that the initial results are driven by the differential presence of multi-region firms in large competitive markets, which due to scale economies have a disproportionate tendency to train. The fixed effects point estimates are quite comparable to those in Table 8 (with $\mathrm{p}<.01$ for 3 of 4 estimates), indicating that training provision at multi-region firms is also quite sensitive to local market conditions. .50

\section{Magnitudes}

The estimated impact of concentration on training is of meaningful economic magnitude. Taking the example of word-processing, the standard deviation of the Herfindahl is approximately 0.25 (also equal to its mean) while the point estimate of the Herfindahl coefficient in the word processing equation is -0.38 . A one standard deviation increase in market competition is therefore predicted to increase wordprocessing training's prevalence by about 9 percentage points. Using a base frequency of 63 percent (Table 1), this yields an elasticity of approximately -0.15 , also implying a sizable 15 percent growth per

\footnotetext{
${ }^{48}$ Occupational share variables correspond to the nine major occupation groups. Two share variables are included for white, one for clerical/sales, and three for blue collar (with one share variable is omitted in each of the three collars). Variables sum to one within a collar.

${ }^{49}$ Estimates that include the log market size measure but exclude the Herfindahl generally find a significantly positive market size effect, suggesting that both variables proxy competitive conditions but that the Herfindahl is the more meaningful measure. As would be expected given this collinearity, estimates that exclude the market size measure yield a larger and more statistically significant Herfindahl coefficient.

${ }^{50}$ Consistent with the notion that firm-wide economies render training less sensitive to individual establishment size, the establishment size coefficient is substantially attenuated in these models.
} 
standard deviation increase in competition. The comparable elasticity for data entry training is -0.23 and for any computer training is -0.09 .

\section{Instrumental variables estimates and other specification checks}

If unobserved factors that vary at the MSA-occupation level drive both THS market concentration and training provision, the estimates above would be biased. A solution to this problem is to use an instrumental variable that influences market concentration directly but is plausibly independent of training provision except via its impact on concentration. A candidate instrument is the scale of the 'target market' facing THS firms, in particular the level of permanent (non-THS) occupational employment in the MSA. Since THS establishments supply workers to fill short-term vacancies in permanent positions, the size of permanent occupational employment in a given MSA will clearly impact the size of THS employment in the same occupation and MSA. Moreover, if there is a minimum efficient scale to operating a THS establishment, a larger target market will all else equal lead to lower THS employer concentration.

To explore this relationship, Figure 2 plots log permanent employment against the log THS Herfindahl by occupational collar for 89 MSAs matched between the OCS data and the 1990 Census IPUMS 1 percent sample. The figure reveals a sizable, well-determined negative relationship, indicating that a considerable share of the variation in THS concentration is accounted for by differences in target market size. ${ }^{52} \mathrm{~A}$ drawback to this instrument is that larger permanent employment might impact training provision not through concentration but simply through market scale. As a check on this possibility, instrumental variables estimates also control for log MSA-collar THS employment. If this variable is found to positively impact training propensity conditional on the instrumented Herfindahl, this would suggest that the exclusion restriction is invalid.

Table 9 presents instrumental variables estimates of the training-concentration relationship using as instruments for log MSA-collar THS concentration the log of 1990 permanent MSA-collar employment

\footnotetext{
${ }^{51}$ Implied training elasticities for multi-region firms are comparable but slightly lower due to higher base frequencies at these firms.

${ }^{52}$ A regression of the log THS MSA-collar Herfindahl on log permanent MSA-collar employment yields an R-squared of 0.56 , 0.53 , and 0.57 for white collar, clerical/sales, and blue collar occupations respectively.
} 
and its square interacted with collar dummies. ${ }^{-3}$ Note that these estimates use the log rather than the level of the Herfindahl index since, as Figure 2 makes evident, the relationship between the log Herfindahl and log permanent employment is approximately linear. The instrumental variable estimates reinforce the findings from the OLS models. Concentration continues to exert a strong negative impact on training provision. Elasticities are somewhat larger for IV than OLS estimates, a pattern that may result from the reduction in measurement error when instrumenting the Herfindahl. Given the concern raised above about distinguishing the impact of market concentration from market scale, it is notable that log MSA-collar THS employment has a weakly negative effect on training propensity in each of these specifications.

OLS models were also estimated using the log of the Herfindahl, yielding smaller elasticities and weaker while still significant t-statistics. $\stackrel{54}{.}$ A quadratic Herfindahl term was never significant. Because the 'difference-in-difference' estimates above are necessarily somewhat restrictive, I also provide in Appendix Table B estimates of the impact of concentration on training propensity performed separately by collar and excluding (by necessity) MSA fixed effects. Unlike the earlier models, these 'difference' estimates identify the concentration-training relationship using exclusively inter-market variation in concentration. Although their precision is substantially reduced by exclusion of MSA fixed effects, they confirm that a negative training-concentration relationship obtains for all training outcomes and collars.

To summarize, THS establishments offer more training in markets where competition is estimated to be more strenuous, even across establishments belonging to the same firm. These facts are consistent with the model. A less favorable reading, however, is that skills training is primarily a non-wage benefit like paid vacation that firms offer in response to heightened market competition. To distinguish the paper's monopsony model from this alternative hypothesis, it is necessary to ask whether training and nontraining firms to respond differentially to competition.

\subsection{The impact of concentration on wages}

Because in the present model competition induces firms to provide additional productive training, a

\footnotetext{
${ }^{53}$ F-statistics for first-stage instrumental variables estimates reject the null at the 0.001 level in all cases.

${ }^{54}$ A table of log Herfindahl concentration-training estimates comparable to Table 8 is available from the author.
} 
distinct prediction is that competition yields differentially greater wage gains for workers at training than at non-training establishments. Since at the separating equilibrium (and in the estimates above), trainees earn less than non-trainees, the model implies that the wages of both groups will rise with competition while the gap between them narrows.

\section{A. Estimates of the impact of concentration on wages at training and non-training establishments}

To explore this implication, I estimate equation (e1) augmented with the MSA-collar Herfindahl measure, initially entered in non-interacted form and later interacted with training policy variables. The Herfindahl is specified in log form so that regression coefficients may be read as elasticities. Pooled and fixed effects estimates are found in panel A of Table 10. The first column, which includes the $\log$ Herfindahl, 40 major occupation indicators, log establishment size, log MSA-collar THS employment, and region fixed effects, indicates a Herfindahl-wage elasticity of -0.027 .

To test the implication that wages respond differentially at training and non-training establishments, column (2) replaces the Herfindahl main effect with an indicator for 'training provided' and two interactions: Herfindahl times 'training provided' and Herfindahl times 'no training provided.' Consistent with the model, the point estimates for the wage-concentration elasticity appear substantially greater at training than non-training establishments, -0.034 and -0.012 respectively, although the data do not reject the null hypothesis of equality between the two coefficients $(p=0.17)$.

Fixed effects estimates of these models provide larger and more statistically significant point estimates. The non-interacted Herfindahl-wage specification indicates a concentration-wage elasticity of 0.61. Interacting the Herfindahl measure with training and non-training indicators reveals substantially greater wage responsiveness at establishments offering training. In column (4), the Herfindahl-Training elasticity is estimated at -0.068 and the Herfindahl-No-Training elasticity at -0.031 , and the hypothesis of equality between the two coefficients is rejected at the .05 level. The column (4) estimate implies that in a fully concentrated market, wages at training establishments would be 9.9 log points below non-training establishments, while in a market at the mean sample concentration (log Herfindahl equal to -2.04$)$, this gap would be only $2.4 \mathrm{log}$ points. A one-standard increase in concentration (from the mean to -1.25 ) is 
predicted to increase this gap to $5.3 \log$ points.

\section{B. Instrumental variables estimates and specification checks.}

As a check on the OLS results, Panel B of Table 10 presents instrumental variables estimates of these models. ${ }^{55}$ For both pooled and fixed effects samples, the IV estimates indicate a significant Herfindahlwage elasticity. Moreover, this elasticity is substantially larger at training than non-training establishment, although one cannot reject the null of equality between the training and non-training coefficients at conventional significance levels. Importantly, log MSA-collar THS employment has no significant wage impact in these estimates.

To ensure that the estimates are not driven by functional form or white collar/non-white collar differences, models were also estimated using a non-log Herfindahl measure and excluding white collar observations. These specification tests yielded comparable results. Bivariate comparisons of mean wages at training and non-training establishments by collar and major occupation within market concentration quartiles also support the regression results. Most notably, the wage gap between training and nontraining establishments in the first $1^{\text {st }}$ and $4^{\text {th }}$ quartiles is substantially smaller in less concentrated markets, both for clerical and blue collar occupations overall and for 5 of 9 detailed occupations. As with the wage-training results, the relationships are less visible for white collar workers. 6

\section{Policy interacted specifications}

Since the voluntary training policy is at the core of the monopsony model, it is here where we would expect to find a substantial relationship. To check this implication, I augment the wage models above by interacting the log Herfindahl measure with each policy variable. Note that this multiple interactions specification is potentially difficult for the data to identify because firms may hold multiple polices.

Despite this limitation, the pattern of coefficients found in Table 11 demonstrates that the concentration-wage effect is primarily mediated through firms offering an 'all/volunteers' policy. Most notably, the fixed effect estimates in Panel B find a significant wage-concentration elasticity for the

\footnotetext{
${ }^{55}$ Instruments are specified as in table 9. F-statistics for first-stage estimates reject the null at the 0.001 level in all cases.

${ }^{56}$ A detailed table of bivariate comparisons is available from the author.
} 
all/volunteers policy while coefficients for the other Herfindahl-policy interactions and the Herfindahl-notraining interaction are insignificant and close to zero.

\section{Discussion}

The estimates in Tables 10 and 11 support the contention that market competition yields higher THS wages. Most notably, this wage effect is significantly greater for workers at training than non-training establishment, even with a given firm. Moreover, consistent with the monopsony framework, the effect is limited to establishments offering unrestricted training. Since wages at training establishments are on average lower than at non-training establishments, the results suggest that firms' ability to extract the costs and/or returns from up-front training is reduced by market competition.

As noted above, if training were simply a job amenity like vacation or sick pay, an alternative reading would be that firms augment their training, wages and perhaps other benefits, as competitive conditions demand. Yet, this explanation would leave a puzzle as to why firms performing training appear to raise their wages significantly more than others. This pattern suggests that there is something distinctive about training, a view supported by survey evidence from ALM. Respondents were asked, "Hypothetically, let's say that conditions in your local temporary market got tougher because several competing offices opened nearby. How likely are you to take the following steps?" A large majority of respondents was likely to "increase wages" (68 percent) or "offer more attractive training opportunities" (62 percent). By contrast, only a minority was likely to "increase vacation, holiday or sick benefits" (33 percent) or to "reduce qualifications required for hire (15 percent)." Notably, the fraction likely to increase wages was 23 percent greater $(\mathrm{p}<.05)$ at training establishments than non-training establishments.

A final direct test of the conceptual framework is to ask whether the markup that training establishments command is higher than at non-training establishments. ${ }^{67}$ Establishments surveyed by ALM were asked to report their typical wage markup on assignments within their major occupation. A

\footnotetext{
${ }^{57}$ This markup should be distinguished from the parameter $\pi$ in the model. The margin between training firms' wages and their bill rate in the model is equal to $\pi$ plus a term equal to the cost of training and a fraction of the difference between trainees' productivity and their outside wage as is visible in (10). This distinction is important because, in the model, $\pi$ does not differ between training and non-training firms whereas the margin between wages and client bill rates is strictly higher at training firms.
} 
regression of their responses on occupation and MSA main effects and an indicator variable for provision of free training reveals that within the same MSAs and occupations, the wage markup at training establishments averages 12 percent ( 5.5 percentage points, $\mathrm{p}<.01)$ above that at non-training establishments, a pattern that holds across all three major occupational collars and is significant in the case of clerical/sales and blue collar occupations. This pattern is difficult to reconcile with a strictly competitive view of the THS market, particularly given the finding that training establishments screen for workers of higher quality and pay lower wages.

\section{Summary and conclusion}

The principal argument of this paper is that training may usefully be viewed as a device for recruiting and screening workers possessing greater motivation and ability to learn. The argument rests on three observations: first, training is more productive and therefore valuable to high ability workers; second, workers have some prior information about their ability that is not initially visible to employers; and third, firms are able to learn about ability through skills training. Under these conditions, the model indicates that firms may be able to offer a package of wages and up-front general skills training that induces selfselection by ability, generating short-run monopsony profits.

The idea that training may serve as a screening mechanism is not at odds with the canonical view of training as a human capital investment; in fact, the model outlined here relies on the assumption that training is both productive, and differentially so with workers of higher ability. A key distinction, however, is that in the Becker model, workers pay ex ante or contemporaneously for general training, whereas in the framework explored here, training is given up-front while training costs and returns are shared ex post by worker and firm. A second contrast lies in the predicted relationship between training and market competition. In the standard model, a movement from monopsony to competition shifts the costs and benefits of training from firm to worker without altering the prevalence or depth of training. In the present model, firms' general under-provision of training makes it optimal for them to train more as

\footnotetext{
${ }^{58}$ The fact that training establishments command a higher markup provides further evidence against the view that they provide unobservably lower quality workers.
} 
competitive conditions tighten, thereby narrowing the earnings gap between trainees and non-trainees.

Two conclusions follow from this research. First, as noted above, the rapid growth of THS employment in the U.S. and increasingly in European and Asian labor markets has led many economists to ask what specifically is the service that THS firms provide for which demand is growing so rapidly (cf., OECD, 1999). The answer provided here is that beyond providing spot market labor, THS firms gather and sell information about worker quality to their clients. Consistent with this view, recent data indicate that employers increasingly use THS arrangements for worker screening. Additionally, in some sectors, THS firms have become a primary conduit for auditioning and hiring new workers (Ballantine and Ferguson, 1999; U.S. Department of Labor, 1999). Hence, the rapid growth of THS as a labor market information broker implies that the demand for worker screening is rising.

Second, while the role of private information in general skills training has received considerable theoretical attention, empirical evidence has proved much more elusive, no doubt because informationbased models are notoriously difficult to test. By studying employer-sponsored general skills training in a setting where traditional explanations appear non-viable, the present analysis suggests that private information is indeed central to an explanation of why temporary help firms provide nominally free general skills training.

Recent data from the Bureau of Labor Statistics reveal that U.S. employers spent 16.6 billion dollars on direct employee training costs in 1994. Of this total, 3.4 billion (20 percent) was paid to direct tuition reimbursements and outside training funds, expenditures which almost certainly constitute primarily general training (Frazis et al., 1998). This figure, which amounts to $\$ 91$ per trainee, is only slightly below the per-worker training investments made by THS firms in the same year. While present knowledge tells us little about how much of this general training is in fact paid up-front by employers, the current analysis indicates that this share could be considerable. 


\section{References}

Abraham, Katherine and Susan K. Taylor (1996) "Firm's Use of Outside Contractors: Theory and Evidence." Journal of Labor Economics, 14(3), 394 - 424.

Acemoglu, Daron (1999) "Changes in Unemployment and Wage Inequality: An Alternative Theory and Some Evidence” American EconomicReview, 89(5), December, 1259 - 1278.

Acemoglu, Daron and Jörn-Steffen Pischke (1998) "Why Do Firms Train: Theory and Evidence." Quarterly Journal of Economics, 113(1), February, 79 - 199.

Acemoglu, Daron and Jörn-Steffen Pischke (1999) "The Structure of Wages and Investment in General Training." Journal of Political Economy, 107(3), 539 - 572.

Akerlof, George A. (1970) “The Market for 'Lemons:' Quality Uncertainty and the Market Mechanism.” Quarterly Journal of Economics, 84(3), August, 488 - 400.

Altonji, Joseph G. and James R. Spletzer (1991) "Worker Characteristics, Job Characteristics, and the Receipt of On-the-Job Training." Industrial and Labor Relations Review, XLV, 58 - 79.

Autor, David (2000) “Outsourcing at Will: Unjust Dismissal Doctrine and the Growth of Temporary Help Employment." mimeograph, MIT, February.

Autor, David H., Frank Levy and Richard J. Murnane (1999) "Skills Training in the Temporary Help Sector: Employer Motivations and Worker Impacts. A Report to the Department of Labor Education and Training Administration." September.

Ballantine, John and Ronald Ferguson (1999) "Labor Demand for Non-College Educated Young Adults" mimeograph, Harvard University Kennedy School of Government.

Barron, John M., Mark C. Berger, and Dan A. Black (1997) On-the-Job Training. (Kalamazoo: W.E. Upjohn Institute for Employment Research).

Bartel, Ann P. and Nachum Sicherman (1998) "Technological Change and the Skill Acquisition of Young Workers.” Journal of Labor Economics, 16(4), 718 - 755.

Becker, Gary (1964) Human Capital. (Chicago: University of Chicago Press).

Bishop, John H. (1996) "What We Know about Employer-Provided Training: A Review of the Literature" Cornell University, Center for Advanced Human Resources Studies Working Paper, 96-09.

Blinder, Alan S. and Alan B. Krueger (1996) "Labor Turnover in the USA and Japan: A Tale of Two Countries.” Pacific Economic Review, 1, 27 - 57.

Castro, Janice (1993) “Disposable Workers.”Time, March 29, 40 - 47.

Chang, Chun and Yijiang Wang (1996) "Human Capital Investment under Asymmetric Information: The Pigovian Conjecture Revisited.” Journal of Labor Economics, 14(3), 505 - 519.

Cohany, Sharon R. (1996) “Workers in Alternative Employment Arrangements." Monthly Labor Review, October, $31-45$. 
Cohany, Sharon R. (1998) "Workers in Alternative Employment Arrangements: A Second Look." Monthly Labor Review, November, 3 - 21.

Dertouzas, James N., Elaine Holland and Patricia Ebener (1988) “The Legal and Economic Consequences of Wrongful Termination.” Rand Corporation Document R-3602-ICJ.

Dertouzas, James N. and Lynn A. Karoly (1992) “Labor-Market Responses to Employer Liability.” Rand Corporation Document R-3989-ICJ.

Evans-Correia, Kate (1991) “Testing and Training Office Temporaries.” Purchasing, August 15, 95 - 99.

Frazis, Harley, Maury Gittleman, Michael Horrigan, and Mary Joyce (1998) "Results from the 1995 Survey of Employer-Provided Training" Monthly Labor Review, June, 3 - 13.

Gibbons, Robert and Lawrence F. Katz (1991) “Layoffs and Lemons.” Journal of Labor Economics, 9, $351-380$.

Golden, Lonnie and Eileen Appelbaum (1992) "What Was Driving the 1982-88 Boom in Temporary Employment? Preferences of Workers or Decisions and Power of Employers." American Journal of Economics and Sociology, 51(40), October, 473 - 493.

Heckman, James J. and Guilherme Sedlacek (1985) "Heterogeneity, Aggregation, and Market Wage Functions: An Empirical Model of Self-Selection in the Labor Market." Journal of Political Economy, 93(6), 1077 - 1125.

Heckman, James J. and Guilherme Sedlacek (1990) "Self-Selection and the Distribution of Hourly Wages.” Journal of Labor Economics, 8(1), S329 - 63.

Houseman, Susan N. (1997) “Temporary, Part-Time, and Contract Employment in the United States: A Report on the W.E. Upjohn Institute's Employer Survey on Flexible Staffing Policies." (Kalamazoo, Michigan: W.E. Upjohn Institute for Employment Research).

Houseman, Susan N. and Anne E. Polivka (1998) "The Implications of Flexible Staffing Arrangements for Job Security.” Mimeograph, W.E. Upjohn Institute for Employment Research.

Ippolito, Richard A. (1997) Pension plans and employee performance: Evidence, analysis, and policy. (Chicago and London: University of Chicago Press).

Kalleberg, Arne L., Edith Rasell, Naomi Cassirer, Barbara F. Reskin, Ken Hudson, David Webster, Eileen Appelbaum, Roberta M. Spalter-Roth (1997) "Nonstandard Work, Substandard Jobs: Flexible Work Arrangements in the U.S.” (Washington, DC: Economic Policy Institute).

Katz, Aliakim and Adrian Ziderman (1990) "Investment in General Training: The Role of Information and Labour Mobility.” The Economic Journal, 100, 1147 - 1158.

Katz, Lawrence F. and Alan B. Krueger (1999) "The High-Pressure U.S. Labor Market of the1990s.” Brookings Papers on Economic Activity: Macroeconomics, 99(1).

Krueger, Alan B. (1991) “The Evolution of Unjust Dismissal Legislation in the United States." Industrial and Labor Relations Review, 44 (4), July, $644-660$. 
Krueger, Alan B. (1993) “How Computers Have Changed the Wage Structure.” Quarterly Journal of Economics, 108(1), $33-60$.

Levy, Frank and Richard Murnane (1996) Teaching the New Basic Skills. (New York: Free Press).

Loewenstein, Mark A. and James R. Spletzer (1998) "Dividing the Costs and Returns to General Training" Journal of Labor Economics, 16, 142 - 171.

Mangum, Garth, Donald Mayall, and Kristin Nelson (1985) “The Temporary Help Industry: A Response to Dual Internal Labor Markets." Industrial and Labor Relations Review, 38(4), July, 599 - 611.

Miles, Thomas J. (forthcoming) "Common Law Exceptions to Employment at Will and U.S. Labor Markets" Journal of Law, Economics, and Organization.

National Association of Temporary and Staffing Services (1996a) "Special Temporary Employee Annual Turnover Report.” Mimeograph, NATSS.

National Association of Temporary and Staffing Services (1996b) "Special Training Survey Shows Temporary Help and Staffing Services Are a Major Source of Skills Training." Alexandria, VA., News Release, December 16.

National Association of Temporary and Staffing Services (1996c) "Temporary Help Employment Experiences Strong Growth in $2^{\text {nd }}$ Quarter.” Alexandria, VA., News Release, September 24.

National Association of Temporary and Staffing Services (1996d) "Temporary Help and Staffing Services 1996-1997 Performance Data."

National Association of Temporary and Staffing Services (undated) "How to Buy Temporary Help/Staffing Services." Unpublished article available for download at http://www.natss.org.

National Association of Temporary and Staffing Services (1998) “Annual Analysis" http://www.natss.org/staffstats/analysis.htm, accessed on 1/24/2000.

Oberle, Joseph (1990) “Manpower Inc.: Training Because There’s No Other Way.” Training, v. 27, March, $57-62$.

OECD (1993) Employment Outlook: 1993. (Paris: OECD).

OECD (1999) Employment Outlook: 1999. (Paris: OECD).

Polivka, Anne E. (1996) “Are Temporary Help Agency Workers Substitutes for Direct Hire Temps? Searching for an Alternative Explanation of Growth in the Temporary Help Industry." mimeograph, Bureau of Labor Statistics, April.

Rosen, Sherwin (1974) "Hedonic Prices and Implicit Markets.” Journal of Political Economy, 82 (1), 34 -55 .

Rothschild, Michael and Joseph E. Stiglitz (1976) "Equilibrium in Competitive Insurance Markets: An Essay on the Economics of Information" Quarterly Journal of Economics, 90(4), 630 - 49.

Ruggles Steven, Matthew Sobek et al. (1997), Integrated Public Use Microdata Series: Version 2.0, Minneapolis: Historical Census Projects, University of Minnesota. 
Salop, Joanne and Steven Salop (1976) "Self-Selection and Turnover in the Labor Market." Quarterly Journal of Economics, 90(4), November, 619 - 27.

Salop, Steven (1979) “Monopolistic Competition with Outside Goods.” Bell Journal of Economics, 10, $141-156$.

Segal, Lewis M. and Daniel G. Sullivan. (1997a) “The Growth of Temporary Services Work.” Journal of Economic Perspectives, Spring, 11 (2), 117 - 136.

Segal, Lewis M. and Daniel G. Sullivan. (1997b) "The Nature of Temporary Services Employment: Evidence from State UI Data.” Mimeograph. Federal Reserve Bank of Chicago, December.

Segal, Lewis M. and Daniel G. Sullivan (1998) "Wage Differentials for Temporary Services Work: Evidence from Administrative Data" Federal Reserve Bank of Chicago Working Paper WP-9823, December.

Spence, Michael (1973) “Job Market Signaling.” Quarterly Journal of Economics, 87(3), 355-374

Staffing Industry Review (1998) “Surveys Find More Employers Relying on Staffing Firms” 3(5), September/October, $42-48$.

Steinberg, Bruce (1994) “1994 Profile of the Temporary Workforce.” Contemporary Times, Spring.

Steinberg, Bruce (1998) “1997 Profile of the Temporary Workforce.” Contemporary Times, Spring.

Tirole, Jean (1998) The Theory of Industrial Organization, Cambridge: The MIT Press.

U.S. Department of Labor (1995) Report on the American Workforce. (Washington, DC: Government Printing Office)

U.S. Department of Labor (1996) “Occupational Compensation Survey: Temporary Help Supply Services, November 1994.” Bulletin 2482, August.

U.S. Department of Labor (1999) Report on the American Workforce. (Washington, DC: Government Printing Office). 


\section{Appendix}

\section{A. Alternative equilibria.}

If (7) is satisfied, the separating equilibrium obtains. If (7) does not hold because all workers wish to train, the ex ante ability of the applicant pool at each firm will equal the population average $(1-\rho)$ and firms' chosen training level will be $\hat{\tau}$ which satisfies:

$$
c^{\prime}(\hat{\tau})=(1-\lambda) \cdot(1-\rho) \cdot\left\lceil 1-\frac{\lambda(1-\rho)}{(\lambda(1-\rho)+\rho)}\right\rceil
$$

As can be readily checked by comparison with $60, \hat{\tau}<\tau^{*}$. However, at $\hat{\tau}$, training may be unattractive to low ability belief workers, in which case the preferences of these workers will negate both the pooling and separating equilibria and no equilibrium will exist. This non-existence result is similar to Rothschild and Stiglitz (1976). Alternatively, at $\hat{\tau}$, training may be unattractive to all workers, in which case a notraining equilibrium will follow. Finally, training at $\hat{\tau}$ may remain attractive to all workers, in which case a training-only equilibrium will result.

B. Firm I's period 2 monopsony wage of $v(\tau)$ cannot be profitably poached.

Firm 1's period 2 wage is $w_{2}(\tau)=v(\tau)$. If a competing firm were to offer a wage to Firm 1's work force of $w_{c}: v(\tau)<w_{c} \leq(1+\tau)$, Firm 1 would also offer $w_{c}$ to its high ability workers thereby retaining them and earning positive period 2 (per-worker) profits of $(1+\tau)-w_{c} \geq 0$. The competitor, by contrast, would recruit only Firm 1's low ability workers and hence make losses of $-w_{c}<0$. If the competitor instead offered a wage of $w_{c}=(1+\tau)+\varepsilon$, it would recruit all of Firm 1's period 1 workers (high and low ability) and hence make losses of $(1+\tau) \cdot\left(\delta_{h}-1\right)-\varepsilon<0$. Hence, because Firm 1 will counter all raiding wage offers except those that exceed a worker's productivity, Firm 1's strategy of paying $w_{2}(\tau)=v(\tau)$ cannot be profitably poached and therefore poaching does not occur in equilibrium.

C. Equilibrium training and wages increase with a fall in profits.

The value of $\pi$ that allows the firm to attain maximum profitability under multiple entry is: 


$$
\pi^{*}=\frac{(1-\lambda) \delta_{h}\left[\left(1+\tau^{*}\right)-v\left(\tau^{*}\right)\right]-c\left(\tau^{*}\right)}{1-(1-\lambda) \delta_{h}}
$$

At $\pi^{*}$, the profitability constraint is just satisfied (i.e., does not bind) while for $\pi>\pi^{*}$ there is no wagetraining package that satisfies the profit constraint. As can be checked by substituting into (11) the firm's chosen training level at $\pi^{*}$ is equal to its unconstrained value, $\tau^{*}$, given by (6) Setting profitability to $\pi=0$ (the fully competitive level), substituting into (11) and using (6) to obtain an expression for the firm's training choice, $\tau^{0}$, yields:

$$
\frac{c\left(\tau^{0}\right)}{\tau^{0}}=c^{\prime}\left(\tau^{*}\right)+\frac{c^{\prime}\left(\tau^{*}\right)}{\tau^{0}}
$$

This expression shows that the average cost of training at $\tau^{0}$ is greater than the marginal cost of training at $\tau^{*}$, implying by the strict convexity of $c(\cdot)$ that $\tau^{0}>\tau^{*}$. Therefore, the firm's optimal training choice is greater at $\pi=0$ than at $\pi^{*}$. Since (11) is continuous over $\tau \in\left(\tau^{*}, \tau^{* *}\right)$, this implies that $\tau^{\underline{\pi}} \in\left(\tau^{*}, \tau^{* *}\right]$ when $\pi<\pi^{*}$ and hence, $\tau^{\pi}$ is weakly greater than $\tau^{*}$ under all feasible profit conditions and is strictly greater when reservations profits are below their maximum. Using the fact that $\pi<\pi^{*} \Rightarrow \tau^{\pi}>\tau^{*} \Rightarrow c^{\prime}\left(\tau^{\pi}\right)>c^{\prime}\left(\tau^{*}\right)$, we can sign the derivative of training with respect to $\pi$, equation (12) from the text (reproduced below):

$$
\frac{d \tau^{\pi}}{d \pi}=\left\{\begin{array}{cl}
\frac{-\left(1-(1-\lambda) \delta_{h}\right)}{c^{\prime}\left(\tau^{\pi}\right)-c^{\prime}\left(\tau^{*}\right)}<0 & \tau^{*}<\tau^{\pi}<\tau^{* *} \\
0 & \text { elsewhere }
\end{array}\right.
$$

This derivative is negative over the interval $\tau \in\left(\tau^{*}, \tau^{* *}\right)$ since the numerator is positive and the denominator negative. Therefore, optimal training is falling with an increase in reservation profits, and conversely, rising as reservation profits fall.

Note, finally, that a4) is discontinuous at $\tau^{* *}$ because for $\tau>\tau^{* *}$, the marginal cost of additional training exceeds the marginal productivity gain. Hence, for $\pi: 0 \leq \pi<\pi^{* *}$, the firm provides training $\tau^{\pi}=\tau^{* *}$ and pays a positive period 1 wage as given by (14) in the text. 
D. At the profit maximum, it is less costly to increase training and wages than to increase wages alone.

This result is most easily illustrated by setting the profit level to its maximum $\pi=\pi^{*}$. As noted in section $\mathrm{C}$ of the Appendix, training at $\pi^{*}$ is equal to $\tau^{*}$ and the profit constraint is satisfied with equality. Hence, the firm's training and profits are the same as in its unconstrained profit maximization. Assume the firm must raise wages slightly to accommodate market pressure. It can increase its first period wage, yielding a negative first order effects on profits as can be seen by differentiating maximized profits with respect to $w_{1}: \partial \pi^{*} / \partial w_{1}=-1$. Alternatively, the firm may increase training slightly which has two associated costs, greater training expenditures and, because training is publicly observed, higher period 2 wages. However, additional training also increases revenue by raising worker productivity. The net cost is obtained by differentiating maximized profits with respect to $\tau$. Applying the envelope theorem yields:

$$
\left.\frac{\partial \pi^{*}}{\partial \tau}\right|_{\tau=\tau^{*}}=0
$$

Because profits are maximized with respect to training at $\tau^{*}$, the profit-training derivative is zero whereas the wage-training derivative $\left(\partial \pi^{*} / \partial w_{1}\right)$ is strictly negative because first period wages are set by a binding constraint $\left(w_{1} \geq 0\right)$. As was shown in section $\mathrm{C}$ of the Appendix, so long as training is in the range $\tau \in\left[\tau^{*}, \tau^{* *}\right]$, the firm finds it more cost effective to raise wages and training together rather than raising wages alone. What (a5) indicates is that in the neighborhood of $\tau^{*}$, small training-induced wage increases are essentially costless. 
Figure 1: Why additional training is an efficient means to raise wages

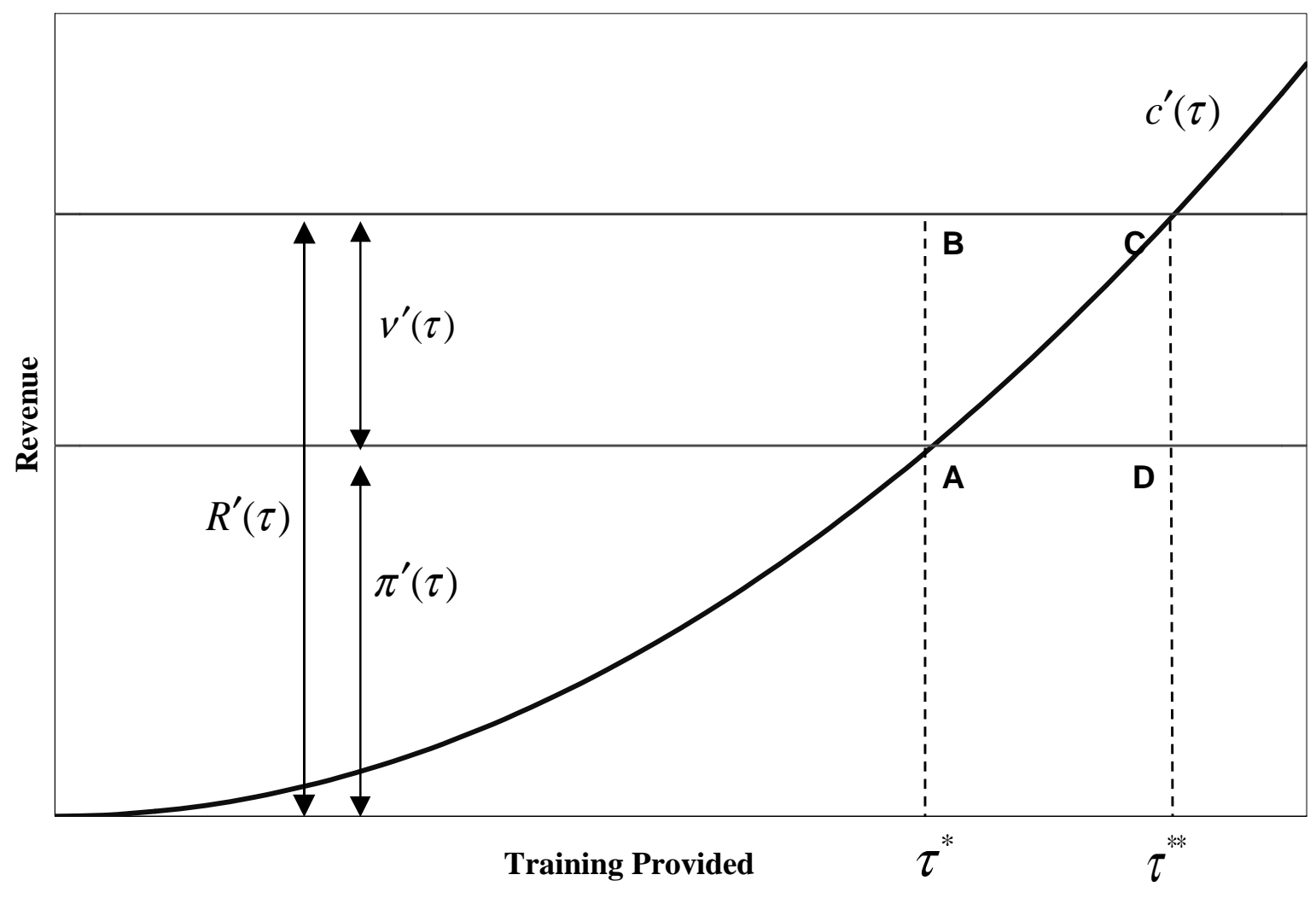


Figure 2: Log THS occupational Herfindahl index and log permanent occupational employment by MSA

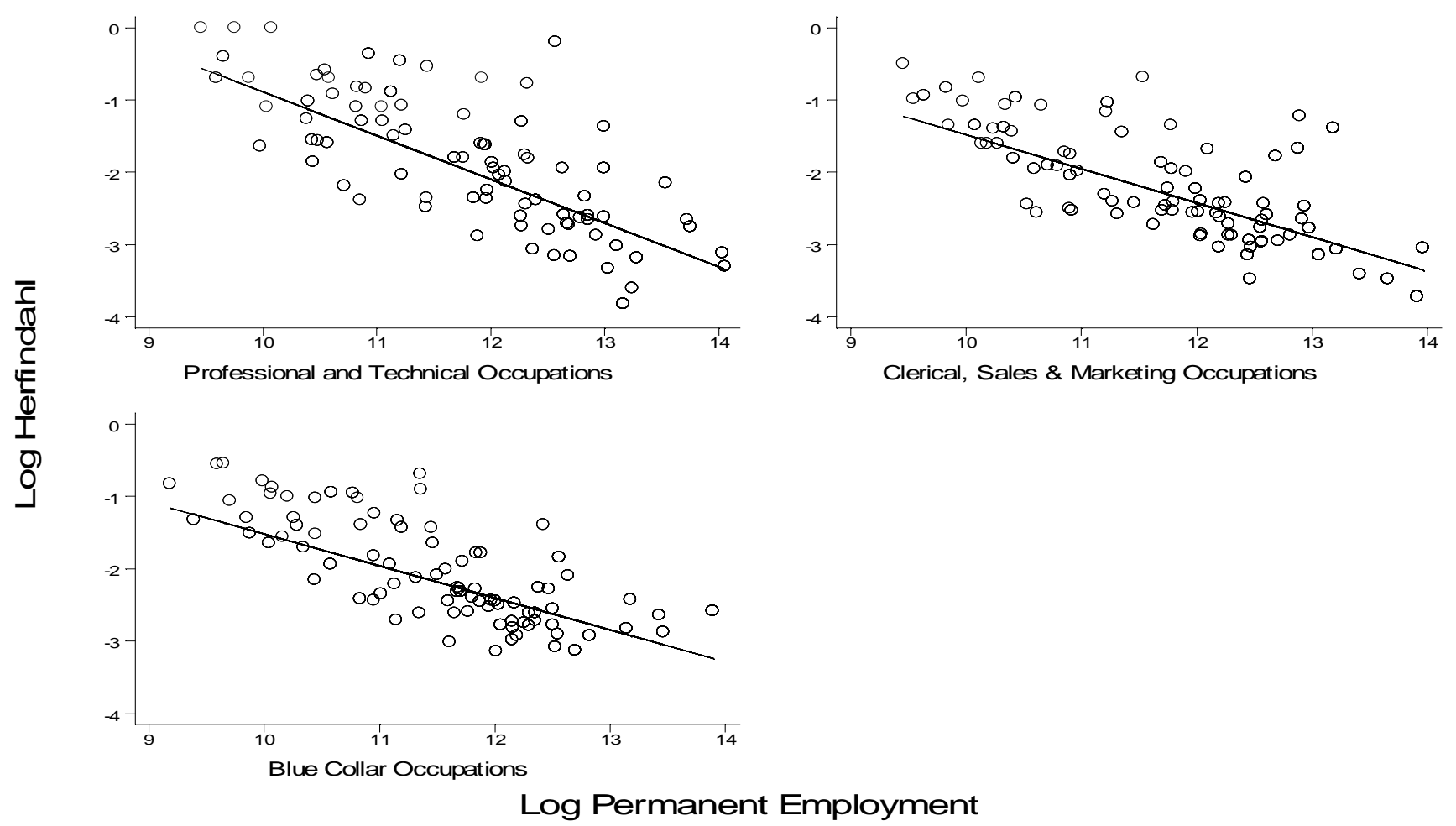

Notes. Points are plotted for 89 Metropolitan Statistical Areas matched between the Occupational Compensation Survey of THS and the 1990 Census IPUMS 1 percent extract. 


\section{Table 1: Skills training: Prevalence and policies at U.S. THS establishments, 1994}

\section{Training provided:}

\section{All skills training}

Any

White collar workers

Clerical/sales workers

Blue collar workers

\section{Computer skills training}

Any

White collar workers

Clerical/sales workers

Blue collar workers

\section{'Soft' skills training}

Any

White collar workers

Clerical/sales workers

Blue collar workers

\section{Training policies:}

(multiple policies possible)

All/Volunteers trained $\quad 66 \%$

Establishment selects trainees $34 \%$

Client requests and pays $\quad 36 \%$

No training

$22 \%$

Training methods used (if training given):

(multiple methods possible)

Computer-based tutorials $\quad 82 \%$

Classroom work, lectures $\quad 45 \%$

Written self-study materials $\quad 52 \%$

Audio-visual presentations $\quad 47 \%$

Other

\section{Detailed training subject frequncies by major occupation group ('collar'):}

Word processing

Data entry

Computer programming languages

Customer service

Workplace rules/on-job conduct

Interview and resume development skills

Communications skills
$70 \%$

$52 \%$

$70 \%$

$58 \%$

$\begin{array}{llcc}\text { Any } & \text { White } & \text { Clerical/ } & \text { Blue } \\ & \underline{\text { Collar }} & \underline{\text { Sales }} & \underline{\text { Collar }}\end{array}$

$\begin{array}{rrrr}63 \% & 23 \% & 75 \% & 13 \% \\ 58 \% & 19 \% & 69 \% & 11 \% \\ 22 \% & 12 \% & 23 \% & 1 \% \\ 41 \% & 27 \% & 47 \% & 12 \% \\ 66 \% & 55 \% & 68 \% & 60 \% \\ 30 \% & 31 \% & 32 \% & 13 \% \\ 14 \% & 15 \% & 14 \% & 10 \%\end{array}$

Notes. White collar occupations are professional specialty, technical, and executive and managerial. Clerical/sales occupations are marketing, sales, and clerical and administrative support. Blue collar occupations are precision production, craft and repair, machine operators, assemblers, and inspectors, transportation and material movement occupations, and handlers, equipment cleaners, and laborers. The sample includes 1,002 temporary establishments supplying white collar, clerical, or blue collar temporary workers (establishments may supply more than one type of worker). Training statistics by collar include only the sub-sample of firms supplying workers in collar ( $n=630,859$, and 755 for establishments supplying white collar, clerical and blue collar workers respectively). All frequencies are weighted by BLS national establishment sampling weights. 
Table 2: Occupation and wage distributions of THS workers used in micro wage models (1994\$)

\begin{tabular}{|c|c|c|c|c|c|c|c|}
\hline & \multirow[b]{2}{*}{$\begin{array}{c}\text { Sample } \\
\text { Count }\end{array}$} & \multirow[b]{2}{*}{$\begin{array}{l}\text { Pop'n } \\
\text { Count } \\
\end{array}$} & \multirow[b]{2}{*}{ Share } & \multirow[b]{2}{*}{$\begin{array}{c}\text { Mean } \\
\text { Wages }\end{array}$} & \multirow[b]{2}{*}{$\begin{array}{c}\text { S.D. } \\
\text { Wages }\end{array}$} & \multicolumn{2}{|c|}{ Reference Samples } \\
\hline & & & & & & $\begin{array}{c}\text { Feb } 95 \text { CPS } \\
\text { Supplemen1 } \\
\text { THS Workers }\end{array}$ & $\begin{array}{c}1994 \text { CPS } \\
\text { All Hourly } \\
\text { Workers } \\
\end{array}$ \\
\hline \multicolumn{8}{|l|}{ White collar } \\
\hline$A l l$ & 23,531 & 84,389 & $9 \%$ & $\$ 17.63$ & $\$ 9.11$ & $\$ 14.93$ & $\$ 13.94$ \\
\hline Professional specialty & 7,934 & 24,961 & $3 \%$ & $\$ 24.11$ & $\$ 8.16$ & $\$ 17.77$ & $\$ 15.62$ \\
\hline Technical & 12,359 & 14,594 & $4 \%$ & $\$ 12.60$ & $\$ 6.22$ & $\$ 15.07$ & $\$ 13.05$ \\
\hline Accountants \& auditors & 3,238 & 3,673 & $1 \%$ & $\$ 17.22$ & $\$ 8.77$ & $\$ 10.53$ & $\$ 12.45$ \\
\hline \multicolumn{8}{|l|}{ Clerical/sales } \\
\hline All & 174,344 & 463,282 & $47 \%$ & $\$ 7.87$ & $\$ 2.66$ & $\$ 7.81$ & $\$ 8.88$ \\
\hline $\begin{array}{l}\text { Clerical \& } \\
\text { administrative support }\end{array}$ & 162,594 & 16,246 & $44 \%$ & $\$ 7.96$ & $\$ 2.68$ & $\$ 7.90$ & $\$ 9.55$ \\
\hline Marketing \& sales & 11,750 & 258,453 & $3 \%$ & $\$ 6.61$ & $\$ 2.03$ & $\$ 6.61$ & $\$ 7.52$ \\
\hline
\end{tabular}

Blue collar

$\begin{array}{lccccccc}\text { All } & 136,013 & 444,895 & 45 \% & \$ 6.02 & \$ 1.70 & \$ 6.23 & \$ 10.71 \\ \begin{array}{l}\text { Precision production, } \\ \text { craft and repair }\end{array} & 14,335 & 19,077 & 5 \% & \$ 7.26 & \$ 2.58 & \$ 7.73 & \$ 12.40 \\ \begin{array}{l}\text { Operators, assemblers, } \\ \text { \& inspectors }\end{array} & 32,718 & 42,047 & 11 \% & \$ 6.26 & \$ 1.82 & \$ 6.04 & \$ 9.68 \\ \begin{array}{l}\text { Transport, material } \\ \text { movement }\end{array} & 3,693 & 4,244 & 1 \% & \$ 7.03 & \$ 2.31 & \$ 6.42 & \$ 10.66 \\ \begin{array}{l}\text { Handlers, equipment } \\ \text { cleaners, \& laborers }\end{array} & 85,267 & 169,188 & 28 \% & \$ 5.67 & \$ 1.24 & \$ 6.00 & \$ 8.65\end{array}$

Notes. All THS means and frequencies are weighted by OCS national establishment probability weights. Workers in service occupations (2,802 observations) are excluded from the sample. 1994 CPS means are drawn from the merged outgoing rotation group files of the 1994 Current Population Survey and are weighted by CPS earnings weights ( $n=119,983)$. 1995 CPS THS worker wages are drawn from the Feb 1995 CPS Contingent Worker Supplement and are weighted by CPS supplement weights and deflated to 1994 dollars using the PCE deflator $(n=295)$. 
Table 3: Comparison of THS worker mean wages at training and non-training establishments by major occupation

\begin{tabular}{|c|c|c|c|c|c|}
\hline & \multicolumn{3}{|c|}{ Log Hourly Wages } & \multirow{2}{*}{$\begin{array}{c}\text { Training } \\
\text { No. Workers } \\
\text { No. Estabs } \\
\end{array}$} & \multirow{2}{*}{$\begin{array}{c}\text { No Training } \\
\text { No. Workers } \\
\text { No. Estabs } \\
\end{array}$} \\
\hline & $\begin{array}{c}\text { Free } \\
\text { Training }\end{array}$ & $\begin{array}{c}\text { No } \\
\text { Training }\end{array}$ & $\begin{array}{c}\text { Differ- } \\
\text { ence }\end{array}$ & & \\
\hline \multicolumn{6}{|l|}{ White collar } \\
\hline All & $\begin{array}{r}2.66 \\
(0.04)\end{array}$ & $\begin{array}{r}2.79 \\
(0.05)\end{array}$ & $\begin{array}{l}-0.13 \\
(0.06)\end{array}$ & $\begin{array}{r}10,497 \\
360\end{array}$ & $\begin{array}{r}13,034 \\
270\end{array}$ \\
\hline Professional specialty & $\begin{array}{r}3.05 \\
(0.02)\end{array}$ & $\begin{array}{r}3.17 \\
(0.03)\end{array}$ & $\begin{array}{l}-0.13 \\
(0.04)\end{array}$ & $\begin{array}{r}2,918 \\
200\end{array}$ & $\begin{array}{r}5,016 \\
170\end{array}$ \\
\hline Technical & $\begin{array}{r}2.41 \\
(0.04)\end{array}$ & $\begin{array}{r}2.45 \\
(0.05)\end{array}$ & $\begin{array}{l}-0.05 \\
(0.06)\end{array}$ & $\begin{array}{r}5,805 \\
274\end{array}$ & $\begin{array}{r}6,554 \\
213\end{array}$ \\
\hline $\begin{array}{l}\text { Accountants and } \\
\text { auditors }\end{array}$ & $\begin{array}{r}2.72 \\
(0.04)\end{array}$ & $\begin{array}{r}2.77 \\
(0.06)\end{array}$ & $\begin{array}{l}-0.06 \\
(0.07)\end{array}$ & $\begin{array}{r}1,774 \\
187\end{array}$ & $\begin{array}{r}1,464 \\
134\end{array}$ \\
\hline \multicolumn{6}{|l|}{ Clerical/sales } \\
\hline All & $\begin{array}{r}2.01 \\
(0.01)\end{array}$ & $\begin{array}{r}2.09 \\
(0.03)\end{array}$ & $\begin{array}{r}-0.09 \\
(0.03)\end{array}$ & $\begin{array}{r}156,419 \\
693\end{array}$ & $\begin{array}{r}17,925 \\
166\end{array}$ \\
\hline $\begin{array}{l}\text { Clerical and admin- } \\
\text { istrative support }\end{array}$ & $\begin{array}{r}2.02 \\
(0.01)\end{array}$ & $\begin{array}{r}2.10 \\
(0.02)\end{array}$ & $\begin{array}{r}-0.08 \\
(0.03)\end{array}$ & $\begin{array}{r}145,997 \\
690\end{array}$ & $\begin{array}{r}16,957 \\
164\end{array}$ \\
\hline Marketing and sales & $\begin{array}{r}1.84 \\
(0.03)\end{array}$ & $\begin{array}{r}1.97 \\
(0.08)\end{array}$ & $\begin{array}{l}-0.13 \\
(0.09)\end{array}$ & $\begin{array}{r}10,422 \\
435\end{array}$ & $\begin{array}{r}1,328 \\
42\end{array}$ \\
\hline \multicolumn{6}{|l|}{ Blue collar } \\
\hline All & $\begin{array}{r}1.76 \\
(0.01)\end{array}$ & $\begin{array}{r}1.78 \\
(0.01)\end{array}$ & $\begin{array}{l}-0.02 \\
(0.02)\end{array}$ & $\begin{array}{r}85,756 \\
461\end{array}$ & $\begin{array}{r}50,257 \\
294\end{array}$ \\
\hline $\begin{array}{l}\text { Precision Production, } \\
\text { craft and repair }\end{array}$ & $\begin{array}{r}1.89 \\
(0.04)\end{array}$ & $\begin{array}{r}1.97 \\
(0.04)\end{array}$ & $\begin{array}{r}-0.08 \\
(0.06)\end{array}$ & $\begin{array}{r}8,193 \\
216\end{array}$ & $\begin{array}{r}6,142 \\
162\end{array}$ \\
\hline $\begin{array}{l}\text { Operators, assemblers, } \\
\text { and inspectors }\end{array}$ & $\begin{array}{r}1.79 \\
(0.02)\end{array}$ & $\begin{array}{r}1.82 \\
(0.02)\end{array}$ & $\begin{array}{r}-0.03 \\
(0.03)\end{array}$ & $\begin{array}{r}19,867 \\
310\end{array}$ & $\begin{array}{r}12,851 \\
187\end{array}$ \\
\hline $\begin{array}{l}\text { Transport, material } \\
\text { movement }\end{array}$ & $\begin{array}{r}1.89 \\
(0.06)\end{array}$ & $\begin{array}{r}1.92 \\
(0.05)\end{array}$ & $\begin{array}{r}-0.03 \\
(0.08)\end{array}$ & $\begin{array}{r}1,884 \\
186\end{array}$ & $\begin{array}{r}1,809 \\
126\end{array}$ \\
\hline $\begin{array}{l}\text { Handlers, equipment } \\
\text { cleaners and laborers }\end{array}$ & $\begin{array}{r}1.72 \\
(0.01)\end{array}$ & $\begin{array}{r}1.71 \\
(0.01)\end{array}$ & $\begin{array}{r}0.01 \\
(0.02)\end{array}$ & $\begin{array}{r}55,812 \\
445\end{array}$ & $\begin{array}{r}29,445 \\
252\end{array}$ \\
\hline
\end{tabular}

Notes. All estimates are weighted by BLS national probability sampling weights. Standard errors (in parentheses) are corrected for clustering of observations at the establishment level. Sample includes 1,002 establishments. Establishments may employ workers in multiple occupations. 
Table 4. OLS estimates of the relationship between establishment training policies and worker wages.

Dependent variable: log hourly wages of THS workers.

\begin{tabular}{|c|c|c|c|c|c|c|}
\hline & (1) & (2) & (3) & (4) & (5) & (6) \\
\hline Training provided & $\begin{array}{r}-0.034 \\
(0.015)\end{array}$ & $\begin{array}{r}-0.019 \\
(0.010)\end{array}$ & $\begin{array}{c}-0.016 \\
(0.009)\end{array}$ & & & \\
\hline All/Volunteers trained & & & & $\begin{array}{r}-0.034 \\
(0.015)\end{array}$ & $\begin{array}{r}-0.025 \\
(0.010)\end{array}$ & $\begin{array}{r}-0.025 \\
(0.010)\end{array}$ \\
\hline Firm selects trainees & & & & $\begin{array}{r}0.009 \\
(0.017)\end{array}$ & $\begin{array}{r}0.005 \\
(0.013)\end{array}$ & $\begin{array}{r}0.006 \\
(0.011)\end{array}$ \\
\hline Client requests/pays for training & & & & $\begin{array}{r}-0.027 \\
(0.017)\end{array}$ & $\begin{array}{r}0.003 \\
(0.012)\end{array}$ & $\begin{array}{r}0.005 \\
(0.012)\end{array}$ \\
\hline $\begin{array}{c}\text { Log of THS employment } \\
\text { in MSA-collar }\end{array}$ & $\begin{array}{r}0.070 \\
(0.009)\end{array}$ & $\begin{array}{r}0.051 \\
(0.012)\end{array}$ & $\begin{array}{r}0.045 \\
(0.010)\end{array}$ & $\begin{array}{r}0.069 \\
(0.009)\end{array}$ & $\begin{array}{r}0.050 \\
(0.011)\end{array}$ & $\begin{array}{r}0.045 \\
(0.010)\end{array}$ \\
\hline Log of establishment size & $\begin{array}{r}-0.019 \\
(0.005)\end{array}$ & $\begin{array}{r}-0.026 \\
(0.004)\end{array}$ & $\begin{array}{l}-0.023 \\
(0.004)\end{array}$ & $\begin{array}{r}-0.018 \\
(0.005)\end{array}$ & $\begin{array}{r}-0.025 \\
(0.004)\end{array}$ & $\begin{array}{r}-0.023 \\
(0.004)\end{array}$ \\
\hline 8 major occupation indicators & Yes & Yes & No & Yes & Yes & No \\
\hline 40 detailed occupation indicators & No & No & Yes & No & No & Yes \\
\hline 102 MSA indicators & No & Yes & Yes & No & Yes & Yes \\
\hline R-squared & 0.55 & 0.62 & 0.69 & 0.54 & 0.62 & 0.69 \\
\hline
\end{tabular}

Notes. All models include 333,888 observations and are weighted by OCS national establishment probability weights. Huber-White standard errors (in parentheses) are corrected for clustering at the establishment level (1,002 establishments). Training policies are not mutually exclusive. 
Table 5. OLS fixed-effects estimates of the relationship between establishment training policies and worker wages.

\begin{tabular}{|c|c|c|c|c|c|c|}
\hline & (1) & (2) & (3) & (4) & $(5)$ & $(6)$ \\
\hline Training provided & $\begin{array}{r}-0.055 \\
(0.016)\end{array}$ & $\begin{array}{r}-0.034 \\
(0.018)\end{array}$ & $\begin{array}{r}-0.017 \\
(0.016)\end{array}$ & & & \\
\hline All/Volunteers trained & & & & $\begin{array}{r}-0.051 \\
(0.016)\end{array}$ & $\begin{array}{r}-0.049 \\
(0.019)\end{array}$ & $\begin{array}{r}-0.037 \\
(\mathbf{0 . 0 1 7})\end{array}$ \\
\hline Firm selects trainees & & & & $\begin{array}{r}-0.024 \\
(0.023)\end{array}$ & $\begin{array}{r}-0.026 \\
(0.040)\end{array}$ & $\begin{array}{r}-0.017 \\
(\mathbf{0 . 0 3 6 )}\end{array}$ \\
\hline Client requests/pays for training & & & & $\begin{array}{r}0.026 \\
(0.024)\end{array}$ & $\begin{array}{r}0.061 \\
(0.039)\end{array}$ & $\begin{array}{r}0.065 \\
(\mathbf{0 . 0 3 5})\end{array}$ \\
\hline $\begin{array}{c}\text { Log of THS employment } \\
\text { in MSA-collar }\end{array}$ & $\begin{array}{r}0.031 \\
(0.013)\end{array}$ & $\begin{array}{r}0.023 \\
(0.013)\end{array}$ & $\begin{array}{r}0.014 \\
(0.012)\end{array}$ & $\begin{array}{r}0.031 \\
(0.013)\end{array}$ & $\begin{array}{r}0.024 \\
(0.013)\end{array}$ & $\begin{array}{r}0.015 \\
(0.012)\end{array}$ \\
\hline Log of establishment size & $\begin{array}{r}-0.033 \\
(0.007)\end{array}$ & $\begin{array}{r}-0.020 \\
(0.007)\end{array}$ & $\begin{array}{r}-0.017 \\
(0.006)\end{array}$ & $\begin{array}{r}-0.033 \\
(0.007)\end{array}$ & $\begin{array}{r}-0.022 \\
(0.007)\end{array}$ & $\begin{array}{r}-0.020 \\
(0.006)\end{array}$ \\
\hline Firm-Fixed Effects & No & Yes & Yes & No & Yes & Yes \\
\hline 8 major occupation indicators & Yes & Yes & No & Yes & Yes & No \\
\hline 40 detailed occupation indicators & No & No & Yes & No & No & Yes \\
\hline $102 \mathrm{MSA}$ indicators & Yes & Yes & Yes & Yes & Yes & Yes \\
\hline R-squared & 0.53 & 0.54 & 0.62 & 0.53 & 0.54 & 0.62 \\
\hline
\end{tabular}

Notes. Huber-White standard errors (in parentheses) allow for clustered errors at establishments. All models are limited to workers employed at multi-region firms (50 firms, 395 establishments, and 201,314 obserrvations). Estimates are weighted by OCS national establishment probability weights. 
Table 6. Summary of regional THS market characteristics in 103 MSAs by major occupation

\begin{tabular}{|c|c|c|c|c|c|c|c|c|}
\hline & \multicolumn{2}{|c|}{ 1. All } & \multicolumn{2}{|c|}{ 2. White collar } & \multicolumn{2}{|c|}{ 3. Clerical/sales } & \multicolumn{2}{|c|}{ 4. Blue collar } \\
\hline & Mean & Std. Dev & Mean & Std. Dev & Mean & Std. Dev & Mean & Std. Dev \\
\hline Surveyed establishments & 9.6 & 8.3 & 6.5 & 5.2 & 8.3 & 7.1 & 7.3 & 5.6 \\
\hline Total establishments & 30.5 & 32.0 & 20.1 & 20.6 & 24.8 & 24.8 & 19.7 & 17.8 \\
\hline Establishment size & 333.2 & 462.1 & 37.4 & 64.6 & 203.0 & 312.2 & 180.1 & 266.3 \\
\hline THS workers surveyed & 3210.5 & 3,910 & 242.6 & 323 & 1692.7 & 2,357 & 1320.5 & 1,636 \\
\hline Total THS employment & 6,471 & 7,968 & 681 & 935 & 3,317 & 4,656 & 2,476 & 3,281 \\
\hline Herfindahl index & 0.21 & 0.27 & 0.29 & 0.28 & 0.23 & 0.25 & 0.24 & 0.25 \\
\hline $\begin{array}{l}\text { Total MSA employment } \\
(1,000 s)\end{array}$ & 801.1 & 812.3 & 264.1 & 271.5 & 227.7 & 232.4 & 184.0 & 188.8 \\
\hline THS employment share & $1.0 \%$ & $0.5 \%$ & $0.3 \%$ & $0.3 \%$ & $1.6 \%$ & $0.8 \%$ & $2.0 \%$ & $1.1 \%$ \\
\hline
\end{tabular}

Notes. All statistics are unweighted means of OCS regional data except for MSA employment data obtained from the 1994 Current Population Survey (CPS) Outgoing Rotation Group files. Columns 1 through 4 contain 104, 97 , 103, and 102 regions respectively. CPS data is used for 83 of 103 regions (the smallest 20 are not identified in CPS public use files). 
Table 7: Establishment linear probability training models specification checks: Dependent variable: Establishment provides word processing training to its employees in collar (white/clerical-sales/blue).

\begin{tabular}{|c|c|c|c|c|c|c|}
\hline & (1) & $(2)$ & (3) & (4) & $(5)$ & (6) \\
\hline $\begin{array}{l}\text { Herfindahl } \\
\text { (in MSA-collar) }\end{array}$ & $\begin{array}{r}-0.245 \\
(0.124)\end{array}$ & $\begin{array}{r}0.155 \\
(0.147)\end{array}$ & $\begin{array}{r}-0.302 \\
(0.102)\end{array}$ & $\begin{array}{r}-0.380 \\
(0.120)\end{array}$ & $\begin{array}{r}-0.338 \\
(0.119)\end{array}$ & $\begin{array}{r}-0.379 \\
(0.122)\end{array}$ \\
\hline Ln(estab size $)$ & & $\begin{array}{r}0.064 \\
(0.011)\end{array}$ & $\begin{array}{r}0.078 \\
(0.009)\end{array}$ & $\begin{array}{r}0.081 \\
(0.009)\end{array}$ & & $\begin{array}{r}0.082 \\
(0.009)\end{array}$ \\
\hline $\begin{array}{l}\text { Ln(MSA-collar } \\
\text { THS emp.) }\end{array}$ & & $\begin{array}{r}0.050 \\
(0.017)\end{array}$ & $\begin{array}{l}-0.028 \\
(0.011)\end{array}$ & $\begin{array}{r}0.018 \\
(0.013)\end{array}$ & & $\begin{array}{r}0.019 \\
(0.013)\end{array}$ \\
\hline Intercept & $\begin{array}{r}0.400 \\
(0.031)\end{array}$ & $\begin{array}{r}-0.351 \\
(0.155)\end{array}$ & $\begin{array}{r}0.550 \\
(0.106)\end{array}$ & $\begin{array}{r}0.080 \\
(0.131)\end{array}$ & $\begin{array}{r}0.672 \\
(0.031)\end{array}$ & $\begin{array}{r}0.065 \\
(0.133)\end{array}$ \\
\hline Collar main effects & No & No & Yes & Yes & Yes & Yes \\
\hline $\begin{array}{l}\text { Occupational share } \\
\text { measures w/in collars }\end{array}$ & No & No & No & No & No & Yes \\
\hline $\begin{array}{l}102 \text { MSA } \\
\text { indicators }\end{array}$ & No & No & No & Yes & Yes & Yes \\
\hline $\mathbf{n}$ & 2,244 & 2,244 & 2,244 & 2,244 & 2,244 & 2,244 \\
\hline R-squared & 0.00 & 0.04 & 0.28 & 0.34 & 0.30 & 0.34 \\
\hline \multicolumn{7}{|c|}{$\begin{array}{l}\text { Notes. Linear probability models are weighted by BLS area probability sampling weights. } \\
\text { Huber-White robust standard errors (in parentheses) allow for grouped errors with MSA- } \\
\text { collar cells. A total of } 1,002 \text { establishments is included. Each establishment may supply } \\
\text { (and train) workers in 1, 2, or } 3 \text { collars, yielding } 630 \text { white, } 859 \text { clerical/sales, and } 755 \text { blue } \\
\text { collar observations. Occupational share variables measure occupational distributions within } \\
\text { collars: } 2 \text { in white collar, } 1 \text { in clerical/sales, and } 3 \text { in blue collar. }\end{array}$} \\
\hline
\end{tabular}


Table 8: Computer skills training and THS market concentration: Pooled and fixed effects models. Dependent variable: Establishment provides computer skills training to its employees in collar (white/clerical-sales/blue).

\begin{tabular}{|c|c|c|c|c|c|c|c|c|}
\hline & \multicolumn{4}{|c|}{ A. Pooled estimates } & \multicolumn{4}{|c|}{ B. Fixed effects estimates } \\
\hline & $\begin{array}{c}\text { Word } \\
\text { Processing } \\
\end{array}$ & $\begin{array}{l}\text { Data } \\
\text { Entry }\end{array}$ & $\begin{array}{c}\text { Computer } A \\
\text { Programming } \\
\end{array}$ & $\begin{array}{l}\text { Any Computer } \\
\text { Skill } \\
\end{array}$ & $\begin{array}{c}\text { Word } \\
\text { Processing } \\
\end{array}$ & $\begin{array}{c}\text { Data } \\
\text { Entry } \\
\end{array}$ & $\begin{array}{c}\text { Computer } \\
\text { Programming } \\
\end{array}$ & $\begin{array}{l}\text { Any Computer } \\
\text { Skill } \\
\end{array}$ \\
\hline & (1) & (2) & (3) & (4) & (5) & (6) & (7) & (8) \\
\hline $\begin{array}{l}\text { Herfindahl } \\
\text { in MSA-collar }\end{array}$ & $\begin{array}{r}-0.379 \\
(0.122)\end{array}$ & $\begin{array}{r}-0.525 \\
(0.120)\end{array}$ & $\begin{array}{r}-0.111 \\
(0.115)\end{array}$ & $\begin{array}{r}-0.254 \\
(0.123)\end{array}$ & $\begin{array}{r}-0.362 \\
(0.131)\end{array}$ & $\begin{array}{r}-0.332 \\
(0.104)\end{array}$ & $\begin{array}{r}0.036 \\
(0.113)\end{array}$ & $\begin{array}{r}-0.401 \\
(0.121)\end{array}$ \\
\hline Log estab size & $\begin{array}{r}0.082 \\
(0.009)\end{array}$ & $\begin{array}{r}0.082 \\
(0.009)\end{array}$ & $\begin{array}{r}0.027 \\
(0.007)\end{array}$ & $\begin{array}{r}0.080 \\
(0.010)\end{array}$ & $\begin{array}{r}0.033 \\
(0.022)\end{array}$ & $\begin{array}{r}0.049 \\
(0.020)\end{array}$ & $\begin{array}{r}0.013 \\
(0.020)\end{array}$ & $\begin{array}{r}0.048 \\
(0.021)\end{array}$ \\
\hline $\begin{array}{l}\text { Log MSA-collar } \\
\text { THS employment }\end{array}$ & $\begin{array}{r}0.019 \\
(0.013)\end{array}$ & $\begin{array}{r}-0.005 \\
(0.015)\end{array}$ & $\begin{array}{r}0.008 \\
(0.013)\end{array}$ & $\begin{array}{r}0.018 \\
(0.014)\end{array}$ & $\begin{array}{r}0.022 \\
(0.019)\end{array}$ & $\begin{array}{r}0.030 \\
(0.018)\end{array}$ & $\begin{array}{r}0.034 \\
(0.019)\end{array}$ & $\begin{array}{r}0.025 \\
(0.020)\end{array}$ \\
\hline Intercept & $\begin{array}{r}0.065 \\
(0.133)\end{array}$ & $\begin{array}{r}0.260 \\
(0.160)\end{array}$ & $\begin{array}{r}-0.080 \\
(0.131)\end{array}$ & $\begin{array}{r}0.096 \\
(0.145)\end{array}$ & $\begin{array}{r}0.193 \\
(0.265)\end{array}$ & $\begin{array}{r}0.220 \\
(0.254)\end{array}$ & $\begin{array}{r}-0.096 \\
(0.251)\end{array}$ & $\begin{array}{r}0.145 \\
(0.284)\end{array}$ \\
\hline Firm fixed effects & No & No & No & No & Yes & Yes & Yes & Yes \\
\hline Collar main effects & Yes & Yes & Yes & Yes & Yes & Yes & Yes & Yes \\
\hline $\begin{array}{l}\text { Occupational share } \\
\text { measures w/in collars }\end{array}$ & Yes & Yes & Yes & Yes & Yes & Yes & Yes & Yes \\
\hline 102 MSA indicators & Yes & Yes & Yes & Yes & Yes & Yes & Yes & Yes \\
\hline $\mathbf{n}$ & 2,244 & 2,244 & 2,244 & 2,244 & 1,020 & 1,020 & 1,020 & 1,020 \\
\hline R-squared & 0.34 & 0.32 & 0.13 & 0.32 & 0.70 & 0.70 & 0.49 & 0.68 \\
\hline
\end{tabular}

Notes. Huber-White standard errors (in parentheses) allow for grouped errors within region-collar cells. Models are weighted by BLS area probability sampling weights. Each establishment may supply (and train) workers in 1, 2, or 3 collars. Pooled estimates include 630 white collar, $859 \mathrm{clerical} / \mathrm{sales}$, and 755 blue collar observations from 1,002 establishments. Fixed effects estimates are limited to 50 multi-region firms, with 285 white collar, 379 clerical/sales, and 356 blue collar observations from 395 establishments. Occupational share variables measure occupational distributions within collars: 2 in white collar, 1 in clerical/sales, and 3 in blue collar. 
Table 9: Computer skills training and THS market concentration: Pooled and fixed-effect Instrumental Variables models. Dependent variable: Establishment provides computer skills training to its employees in collar (white/clerical-sales/blue).

\begin{tabular}{|c|c|c|c|c|c|c|c|c|}
\hline & \multicolumn{4}{|c|}{ A. Pooled IV estimates } & \multicolumn{4}{|c|}{ B. Fixed-effect IV estimates } \\
\hline & $\begin{array}{c}\text { Word } \\
\text { Processing }\end{array}$ & $\begin{array}{l}\text { Data } \\
\text { Entry }\end{array}$ & $\begin{array}{c}\text { Computer } \\
\text { Programming }\end{array}$ & $\begin{array}{l}\text { Computer } \\
\text { Skill }\end{array}$ & $\begin{array}{c}\text { Word } \\
\text { Processing }\end{array}$ & $\begin{array}{l}\text { Data } \\
\text { Entry }\end{array}$ & $\begin{array}{c}\text { Computer } \\
\text { Programming }\end{array}$ & $\begin{array}{l}\text { Any Computer } \\
\text { Skill }\end{array}$ \\
\hline & (1) & (2) & (3) & (4) & (5) & (6) & (7) & (8) \\
\hline $\begin{array}{l}\text { Log Herfindahl } \\
\text { in MSA-collar }\end{array}$ & $\begin{array}{r}-0.287 \\
(0.118)\end{array}$ & $\begin{array}{r}-0.269 \\
(0.125)\end{array}$ & $\begin{array}{r}-0.105 \\
(0.072)\end{array}$ & $\begin{array}{r}-0.203 \\
(0.116)\end{array}$ & $\begin{array}{r}-0.533 \\
(0.189)\end{array}$ & $\begin{array}{r}-0.384 \\
(0.165)\end{array}$ & $\begin{array}{r}-0.186 \\
(0.110)\end{array}$ & $\begin{array}{r}-0.531 \\
(0.210)\end{array}$ \\
\hline Log estab size & $\begin{array}{r}0.084 \\
(0.010)\end{array}$ & $\begin{array}{r}0.084 \\
(0.009)\end{array}$ & $\begin{array}{r}0.028 \\
(0.007)\end{array}$ & $\begin{array}{r}0.082 \\
(0.010)\end{array}$ & $\begin{array}{r}0.035 \\
(0.022)\end{array}$ & $\begin{array}{r}0.050 \\
(0.020)\end{array}$ & $\begin{array}{r}0.014 \\
(0.020)\end{array}$ & $\begin{array}{r}0.050 \\
(0.021)\end{array}$ \\
\hline $\begin{array}{l}\text { Log MSA-collar } \\
\text { THS employment }\end{array}$ & $\begin{array}{r}-0.058 \\
(0.037)\end{array}$ & $\begin{array}{r}-0.072 \\
(0.038)\end{array}$ & $\begin{array}{r}-0.023 \\
(0.026)\end{array}$ & $\begin{array}{r}-0.039 \\
(0.038)\end{array}$ & $\begin{array}{r}-0.083 \\
(0.048)\end{array}$ & $\begin{array}{r}-0.042 \\
(0.042)\end{array}$ & $\begin{array}{r}-0.011 \\
(0.032)\end{array}$ & $\begin{array}{r}-0.078 \\
(0.055)\end{array}$ \\
\hline Intercept & $\begin{array}{r}-0.083 \\
(0.229)\end{array}$ & $\begin{array}{r}0.066 \\
(0.234)\end{array}$ & $\begin{array}{r}-0.102 \\
(0.135)\end{array}$ & $\begin{array}{r}0.014 \\
(0.203)\end{array}$ & $\begin{array}{r}0.015 \\
(0.434)\end{array}$ & $\begin{array}{r}0.006 \\
(4.470)\end{array}$ & $\begin{array}{r}-0.005 \\
(4.278)\end{array}$ & $\begin{array}{r}0.012 \\
(7.518)\end{array}$ \\
\hline Firm fixed effects & No & No & No & No & Yes & Yes & Yes & Yes \\
\hline Collar main effects & Yes & Yes & Yes & Yes & Yes & Yes & Yes & Yes \\
\hline $\begin{array}{l}\text { Occupational share } \\
\text { measures w/in collars }\end{array}$ & Yes & Yes & Yes & Yes & Yes & Yes & Yes & Yes \\
\hline $\begin{array}{l}103 \text { MSA } \\
\text { indicators }\end{array}$ & Yes & Yes & Yes & Yes & Yes & Yes & Yes & Yes \\
\hline $\mathbf{n}$ & 2,182 & 2,182 & 2,182 & 2,182 & 982 & 982 & 982 & 982 \\
\hline R-squared & 0.31 & 0.29 & 0.12 & 0.30 & 0.61 & 0.65 & 0.47 & 0.59 \\
\hline
\end{tabular}

Notes. Huber-White standard errors in parentheses allow for grouped errors within MSA-collar cells. Models are weighted by BLS area probability sampling weights. Fixed effects estimates are limited to multi-region firms. Instruments for the log Herfindahl are log MSA-collar permanent employment and its square interacted with collar dummies (white collar/clerical-sales/blue collar) estimated for 89 matched MSAs using the 1990 Census IPUMS 1 percent extract. Sample is limited to establishments in matched MSAs. 
Table 10. Estimates of the relationship between market concentration and worker wages: Pooled, fixed effect, and instrumental variables models. Dependent variable: $\log$ hourly wages of THS workers.

\begin{tabular}{|c|c|c|c|c|c|c|c|c|}
\hline & \multicolumn{4}{|c|}{ A. OLS estimates } & \multicolumn{4}{|c|}{ B. IV estimates } \\
\hline & $\begin{array}{c}1) \\
\text { Pooled } \\
\end{array}$ & $\begin{array}{c}\text { (2) } \\
\text { Pooled } \\
\end{array}$ & $\begin{array}{c}(3) \\
\text { Fixed- } \\
\text { effects }\end{array}$ & $\begin{array}{c}\text { (4) } \\
\text { Fixed- } \\
\text { effects }\end{array}$ & $\begin{array}{c}\text { (5) } \\
\text { Pooled } \\
\end{array}$ & $\begin{array}{c}\text { (6) } \\
\text { Pooled } \\
\end{array}$ & $\begin{array}{c}(7) \\
\text { Fixed- } \\
\text { effects }\end{array}$ & $\begin{array}{c}(8) \\
\text { Fixed- } \\
\text { effects } \\
\end{array}$ \\
\hline $\begin{array}{l}\text { Log of Herfindahl } \\
\text { in MSA-collar }\end{array}$ & $\begin{array}{r}-0.027 \\
(0.019)\end{array}$ & & $\begin{array}{r}-0.061 \\
(0.022)\end{array}$ & & $\begin{array}{r}-0.117 \\
(0.061)\end{array}$ & & $\begin{array}{r}-0.125 \\
(0.064)\end{array}$ & \\
\hline $\begin{array}{l}\text { Log Herfindahl * } \\
\text { Training provided }\end{array}$ & & $\begin{array}{r}-0.034 \\
(0.020)\end{array}$ & & $\begin{array}{r}-0.068 \\
(0.023)\end{array}$ & & $\begin{array}{r}-0.145 \\
(0.057)\end{array}$ & & $\begin{array}{r}-0.137 \\
(0.060)\end{array}$ \\
\hline $\begin{array}{l}\text { Log Herfindahl } * \\
\quad \text { No training provided }\end{array}$ & & $\begin{array}{r}-0.012 \\
(0.019)\end{array}$ & & $\begin{array}{r}-0.031 \\
(0.023)\end{array}$ & & $\begin{array}{r}-0.096 \\
(0.054)\end{array}$ & & $\begin{array}{r}-0.100 \\
(0.065)\end{array}$ \\
\hline Training provided & & $\begin{array}{r}-0.074 \\
(0.042)\end{array}$ & & $\begin{array}{r}-0.099 \\
(0.049)\end{array}$ & & $\begin{array}{r}-0.148 \\
(0.069)\end{array}$ & & $\begin{array}{r}-0.098 \\
(0.123)\end{array}$ \\
\hline $\begin{array}{c}\text { Log of THS employment } \\
\text { in MSA-collar }\end{array}$ & $\begin{array}{r}0.025 \\
(0.020)\end{array}$ & $\begin{array}{r}0.024 \\
(0.019)\end{array}$ & $\begin{array}{r}-0.021 \\
(0.017)\end{array}$ & $\begin{array}{r}-0.023 \\
(0.017)\end{array}$ & $\begin{array}{r}-0.019 \\
(0.026)\end{array}$ & $\begin{array}{r}-0.019 \\
(0.024)\end{array}$ & $\begin{array}{r}-0.016 \\
(0.024)\end{array}$ & $\begin{array}{r}-0.016 \\
(0.023)\end{array}$ \\
\hline $\begin{array}{c}\text { Log of establishment } \\
\text { size }\end{array}$ & $\begin{array}{r}-0.024 \\
(0.004)\end{array}$ & $\begin{array}{r}-0.024 \\
(0.004)\end{array}$ & $\begin{array}{l}-0.018 \\
(0.007)\end{array}$ & $\begin{array}{r}-0.019 \\
(0.007)\end{array}$ & $\begin{array}{r}-0.006 \\
(0.005)\end{array}$ & $\begin{array}{r}-0.012 \\
(0.004)\end{array}$ & $\begin{array}{r}-0.038 \\
(0.007)\end{array}$ & $\begin{array}{r}-0.041 \\
(0.007)\end{array}$ \\
\hline Firm fixed effects & No & No & Yes & Yes & No & No & Yes & Yes \\
\hline $\begin{array}{l}40 \text { detailed occ. } \\
\text { indicators }\end{array}$ & Yes & Yes & Yes & Yes & Yes & Yes & Yes & Yes \\
\hline MSA indicators & Yes & Yes & Yes & Yes & Yes & Yes & Yes & Yes \\
\hline R-squared & 0.70 & 0.70 & 0.63 & 0.63 & 0.70 & 0.69 & 0.63 & 0.63 \\
\hline $\mathbf{n}$ & 333,888 & 333,888 & 201,314 & 201,314 & 330,577 & 330,577 & 199,097 & 199,097 \\
\hline $\begin{array}{r}\mathrm{H}_{1} \text { : Herfindahl } * \text { Training } \\
\text { Herfindahl } * \text { No trainir }\end{array}$ & & 0.17 & & 0.05 & & 0.07 & & 0.42 \\
\hline
\end{tabular}

Notes. All models are weighted by OCS regional establishment probability sampling weights. Huber-White standard errors (in parentheses) allow for grouped errors by MSA-collar. Pooled estimates include workers at 1,002 establishments; fixed-effects estimates are limited to workers employed by multi-region firms (50 firms, 395 establishments). Instruments for the log Herfindahl are log MSA-collar permanent employment and its square interacted with collar dummies (white collar/clerical-sales/blue collar) estimated for 89 matched MSAs using the 1990 Census IPUMS 1 percent extract. IV samples are limited to establishments in matched MSAs. 
Table 11. Estimates of the relationship between market concentration and worker wages and its interaction with training policies. Dependent variable: log hourly wages

\begin{tabular}{|c|c|c|c|c|}
\hline & \multicolumn{2}{|c|}{ A. Pooled estimates } & \multicolumn{2}{|c|}{ B. Fixed-effects estimates } \\
\hline & (1) & (2) & (3) & (4) \\
\hline $\begin{array}{l}\text { Log Herfindahl* } \\
\text { All/volunteers trained }\end{array}$ & $\begin{array}{r}-0.038 \\
(0.017)\end{array}$ & $\begin{array}{r}-0.028 \\
(0.019)\end{array}$ & $\begin{array}{r}-0.055 \\
(0.024)\end{array}$ & $\begin{array}{r}-0.047 \\
(0.024)\end{array}$ \\
\hline $\begin{array}{l}\text { Log Herfindahl* } \\
\text { Firm selects trainees }\end{array}$ & $\begin{array}{r}0.023 \\
(0.039)\end{array}$ & $\begin{array}{r}0.035 \\
(0.043)\end{array}$ & $\begin{array}{r}0.017 \\
(0.056)\end{array}$ & $\begin{array}{r}0.033 \\
(0.051)\end{array}$ \\
\hline $\begin{array}{l}\text { Log Herfindahl* } \\
\text { Client requests/pays }\end{array}$ & $\begin{array}{r}-0.011 \\
(0.031)\end{array}$ & $\begin{array}{r}-0.028 \\
(0.037)\end{array}$ & $\begin{array}{r}-0.022 \\
(0.056)\end{array}$ & $\begin{array}{r}-0.037 \\
(0.050)\end{array}$ \\
\hline $\begin{array}{l}\text { Log Herfindahl* } \\
\text { No Training }\end{array}$ & $\begin{array}{r}-0.003 \\
(0.010)\end{array}$ & $\begin{array}{r}0.000 \\
(0.008)\end{array}$ & $\begin{array}{r}-0.009 \\
(0.015)\end{array}$ & $\begin{array}{l}-0.003 \\
(0.014)\end{array}$ \\
\hline All/Volunteers trained & $\begin{array}{r}-0.120 \\
(0.048)\end{array}$ & $\begin{array}{r}-0.100 \\
(0.049)\end{array}$ & $\begin{array}{r}-0.154 \\
(0.058)\end{array}$ & $\begin{array}{r}-0.142 \\
(0.057)\end{array}$ \\
\hline Firm selects trainees & $\begin{array}{r}0.058 \\
(0.100)\end{array}$ & $\begin{array}{r}0.094 \\
(0.110)\end{array}$ & $\begin{array}{r}0.028 \\
(0.147)\end{array}$ & $\begin{array}{r}0.077 \\
(0.137)\end{array}$ \\
\hline Client requests/pays & $\begin{array}{r}-0.020 \\
(0.084)\end{array}$ & $\begin{array}{r}-0.067 \\
(0.099)\end{array}$ & $\begin{array}{r}0.004 \\
(0.150)\end{array}$ & $\begin{array}{r}-0.029 \\
(0.135)\end{array}$ \\
\hline Firm fixed effects & No & No & Yes & Yes \\
\hline 8 major occ indicators & Yes & No & Yes & No \\
\hline 40 detailed occ indicators & No & Yes & No & Yes \\
\hline R-squared & 0.63 & 0.70 & 0.55 & 0.63 \\
\hline $\mathbf{n}$ & 333,888 & 333,888 & 201,314 & 201,314 \\
\hline
\end{tabular}

Notes. Huber-White standard errors (in parentheses) allow for grouped errors by MSAcollar. Models are weighted by OCS regional establishment probability sampling weights and include 103 MSA dummies, 40 detailed occupation indicators, log establishment size, and $\log$ MSA-collar THS employment. Pooled estimates include workers at 1,002 establishments. Fixed-effects estimates are limited to workers employed by multi-region firms (50 firms, 395 establishments). 
Appendix Table A. OLS pooled and fixed effects estimates of the relationship between establishment training policies and worker wages by occupational group.

Dependent variable: log hourly wages of THS workers.

\begin{tabular}{|c|c|c|c|c|c|c|}
\hline & \multicolumn{3}{|c|}{ A. Pooled estimates } & \multicolumn{3}{|c|}{ B. Fixed-effects estimates } \\
\hline & $\begin{array}{l}\text { White } \\
\text { Collar }\end{array}$ & $\begin{array}{c}\text { Clerical/ } \\
\text { Sales }\end{array}$ & $\begin{array}{c}\text { Blue } \\
\text { Collar }\end{array}$ & $\begin{array}{l}\text { White } \\
\text { Collar }\end{array}$ & $\begin{array}{c}\text { Clerical/ } \\
\text { Sales }\end{array}$ & $\begin{array}{l}\text { Blue } \\
\text { Collar }\end{array}$ \\
\hline & (1) & $(2)$ & (3) & (4) & (5) & (6) \\
\hline All/volunteers trained & $\begin{array}{r}-0.010 \\
(0.042)\end{array}$ & $\begin{array}{r}-0.038 \\
(0.013)\end{array}$ & $\begin{array}{r}-0.026 \\
(0.012)\end{array}$ & $\begin{array}{r}0.009 \\
(0.162)\end{array}$ & $\begin{array}{r}-0.098 \\
(0.035)\end{array}$ & $\begin{array}{r}-0.050 \\
(0.032)\end{array}$ \\
\hline Firm selects trainees & $\begin{array}{r}-0.041 \\
(0.041)\end{array}$ & $\begin{array}{r}-0.025 \\
(0.015)\end{array}$ & $\begin{array}{r}0.031 \\
(0.014)\end{array}$ & $\begin{array}{r}-0.658 \\
(0.186)\end{array}$ & $\begin{array}{r}0.014 \\
(0.042)\end{array}$ & $\begin{array}{r}-0.023 \\
(0.036)\end{array}$ \\
\hline $\begin{array}{l}\text { Client requests/pays } \\
\text { for training }\end{array}$ & $\begin{array}{r}0.005 \\
(0.036)\end{array}$ & $\begin{array}{r}0.004 \\
(0.016)\end{array}$ & $\begin{array}{r}-0.004 \\
(0.015)\end{array}$ & $\begin{array}{r}0.541 \\
(0.175)\end{array}$ & $\begin{array}{r}0.065 \\
(0.025)\end{array}$ & $\begin{array}{r}0.084 \\
(0.026)\end{array}$ \\
\hline Intercept & $\begin{array}{r}2.963 \\
(0.075)\end{array}$ & $\begin{array}{r}2.351 \\
(0.029)\end{array}$ & $\begin{array}{r}1.789 \\
(0.031)\end{array}$ & $\begin{array}{r}2.262 \\
(0.208)\end{array}$ & $\begin{array}{r}2.070 \\
(0.123)\end{array}$ & $\begin{array}{r}1.669 \\
(0.094)\end{array}$ \\
\hline Detailed occ. Indicators & Yes & Yes & Yes & Yes & Yes & Yes \\
\hline 102 MSA indicators & Yes & Yes & Yes & Yes & Yes & Yes \\
\hline Firm fixed effects & No & No & No & Yes & Yes & Yes \\
\hline R-squared & 0.61 & 0.47 & 0.36 & 0.73 & 0.48 & 0.39 \\
\hline $\mathbf{n}$ & 23,531 & 174,344 & 136,013 & 5,055 & 42,599 & 26,499 \\
\hline
\end{tabular}

Notes. Huber-White standard errors (in parentheses) allow for clustered errors at establishments. All models are weighted by OCS national establishment probability weights. Fixed effects estimates are limited to firms whose training policies vary among establishments. Detailed occupation dummies are included for 14 white collar occupations, 14 clerical/sales occupations, and 10 blue collar occupations in white collar, clerical/sales, and blue collar estimates respectively. Estimates in columns (1) through (3) contain a total of 1,002 establishments, 630 employing white collar, 859 employing clerical/sales, and 755 employing blue collar workers. Column (4) contains 14 firms and 111 establishments. Column (5) contains 21 firms and 137 establishments. Column (5) contains 14 firms and 119 establishments. Training policies are not mutually exclusive. 
Appendix Table B. Establishment linear probability 'difference' training models estimated by collar (white/clerical-sales/blue).

Dependent variable: Establishment provides skills training to workers in collar.

\begin{tabular}{|c|c|c|c|c|}
\hline & $\begin{array}{c}\text { Word } \\
\text { Processing } \\
\end{array}$ & $\begin{array}{l}\text { Data } \\
\text { Entry } \\
\end{array}$ & $\begin{array}{c}\text { Computer } \\
\text { Programming } \\
\end{array}$ & $\begin{array}{c}\text { Any Computer } \\
\text { Skill } \\
\end{array}$ \\
\hline & \multicolumn{4}{|c|}{ A. Technical/Professional Workers } \\
\hline Herfindahl in MSA-collar & $\begin{array}{r}-0.180 \\
(0.148)\end{array}$ & $\begin{array}{r}-0.226 \\
(0.154)\end{array}$ & $\begin{array}{r}-0.014 \\
(0.143)\end{array}$ & $\begin{array}{r}-0.103 \\
(0.167)\end{array}$ \\
\hline Log establishment size & $\begin{array}{r}0.086 \\
(0.016)\end{array}$ & $\begin{array}{r}0.073 \\
(0.016)\end{array}$ & $\begin{array}{r}0.012 \\
(0.016)\end{array}$ & $\begin{array}{r}0.070 \\
(0.017)\end{array}$ \\
\hline $\begin{array}{l}\text { Log MSA-collar THS } \\
\text { employment }\end{array}$ & $\begin{array}{r}-0.001 \\
(0.017)\end{array}$ & $\begin{array}{r}-0.017 \\
(0.017)\end{array}$ & $\begin{array}{r}0.011 \\
(0.012)\end{array}$ & $\begin{array}{r}0.008 \\
(0.017)\end{array}$ \\
\hline \multirow[t]{2}{*}{$\mathbf{n}$} & 630 & 630 & 630 & 630 \\
\hline & \multicolumn{4}{|c|}{ B. Clerical/Sales Workers } \\
\hline Herfindahl in MSA-collar & $\begin{array}{r}-0.411 \\
(0.205)\end{array}$ & $\begin{array}{r}-0.329 \\
(0.213)\end{array}$ & $\begin{array}{r}-0.137 \\
(0.193)\end{array}$ & $\begin{array}{r}-0.241 \\
(0.242)\end{array}$ \\
\hline Log establishment size & $\begin{array}{r}0.091 \\
(0.015)\end{array}$ & $\begin{array}{r}0.111 \\
(0.015)\end{array}$ & $\begin{array}{r}0.053 \\
(0.013)\end{array}$ & $\begin{array}{r}0.089 \\
(0.015)\end{array}$ \\
\hline $\begin{array}{l}\text { Log MSA-collar THS } \\
\text { employment }\end{array}$ & $\begin{array}{r}-0.054 \\
(0.019)\end{array}$ & $\begin{array}{l}-0.090 \\
(0.022)\end{array}$ & $\begin{array}{r}-0.038 \\
(0.016)\end{array}$ & $\begin{array}{r}-0.045 \\
(0.020)\end{array}$ \\
\hline \multirow[t]{2}{*}{$\mathbf{n}$} & 859 & 859 & 859 & 859 \\
\hline & \multicolumn{4}{|c|}{ C. Blue Collar Workers } \\
\hline Herfindahl in MSA-collar & $\begin{array}{r}-0.253 \\
(0.160)\end{array}$ & $\begin{array}{r}-0.132 \\
(0.147)\end{array}$ & $\begin{array}{r}-0.021 \\
(0.026)\end{array}$ & $\begin{array}{r}-0.176 \\
(0.163)\end{array}$ \\
\hline Log establishment size & $\begin{array}{r}0.053 \\
(0.013)\end{array}$ & $\begin{array}{r}0.041 \\
(0.013)\end{array}$ & $\begin{array}{r}-0.005 \\
(0.003)\end{array}$ & $\begin{array}{r}0.055 \\
(0.014)\end{array}$ \\
\hline $\begin{array}{l}\text { Log MSA-collar THS } \\
\text { employment }\end{array}$ & $\begin{array}{r}-0.018 \\
(0.019)\end{array}$ & $\begin{array}{r}-0.015 \\
(0.016)\end{array}$ & $\begin{array}{r}-0.003 \\
(0.002)\end{array}$ & $\begin{array}{r}-0.008 \\
(0.019)\end{array}$ \\
\hline $\mathbf{n}$ & 755 & 755 & 755 & 755 \\
\hline
\end{tabular}

